\title{
Bloody Unfair: Inequality related to Menstruation - Considering the Role of Discrimination Law
}

\author{
Beth Goldblatt* and Linda Steele ${ }^{\dagger}$
}

\begin{abstract}
Drawing on growing social awareness, activism and scholarship, this article examines menstruation as an equality issue and the implications for discrimination law in Australia. It discusses the complex nature of inequality that arises in relation to menstruation. It also considers intersectional discrimination (when a combination of attributes generates a new form of discrimination) that occurs in relation to menstruation facing different groups: women and girls with disabilities, incarcerated women, and transgender, gender-diverse and intersex people. The article considers how some forms of inequality related to menstruation might be addressed through discrimination law (workplace adjustments and provision of menstrual products in carceral settings) and points to limitations of discrimination law or its application, such as in relation to sterilisation of women and girls with disabilities and strip searching of incarcerated women. It concludes that Australian discrimination law can only have a limited impact in addressing menstrual inequality. This is because: (a) the structure of the law is attribute-based and thus cannot address the complex intersections of sex and other attributes; (b) it cannot address structural inequality; and (c) it cannot adequately contend with embodied and abjected legal subjects. These conclusions have radical implications beyond menstruation inequality in contributing to broader discussions of how law can re-imagine gender difference and advance equality.
\end{abstract}

\section{Introduction}

On 3 October 2018 Australian state and territory treasurers agreed to remove the Goods and Services Tax ('GST') on tampons and other menstrual products. This decision is evidence of the success of an 18-year campaign against a law that harms

Associate Professor, Faculty of Law, University of Technology Sydney, New South Wales, Australia; Visiting Associate Professor, School of Law, University of the Witwatersrand, Johannesburg, South Africa.

$\dagger \quad$ Senior Lecturer, Faculty of Law, University of Technology Sydney; Visiting Senior Fellow, Faculty of Law, Humanities and the Arts, University of Wollongong.

Thanks to Liam Elphick for excellent research assistance, and to Belinda Smith, Trish Luker, Isabel Karpin, Nola Ries, Brian Opeskin and Gabrielle Simm for their generous feedback on earlier drafts, and for helpful comments from participants of the Berkeley Comparative Equality and AntiDiscrimination Law Study Group Annual Conference, Melbourne, June 2018 and the Law and Society Association of Australia and New Zealand Conference, Wollongong, December 2018. This article was supported by funding from UTS Law | Health | Justice Research Centre. 
a large section of the population financially because of their biology. ${ }^{1}$ Similar tax activism and campaigns for menstrual pride and dignity across a number of western nations demonstrate growing interest in issues of menstruation and its relationship to political, social and economic equality. ${ }^{2}$ There has also been increased attention to menstruation by human rights and development groups, particularly in relation to women's rights to water, sanitation and hygiene. ${ }^{3}$ In this article, we draw on this growing social awareness, and a developing scholarship, ${ }^{4}$ to examine menstruation as an equality issue and the implications for discrimination law in Australia. We consider how some forms of inequality related to menstruation might be addressed through discrimination law and point to gaps where the law or its application has limitations. $^{5}$

The new activism and policy victories are a response to the stigma, silence and shame that accompanies menstruation in many societies. Despite decades of feminist success in improving women's access to work, politics, education and other areas of public participation, aspects of their bodily experience remain as barriers to their full equality. Menstruation, generally a monthly occurrence for girls and women from puberty to menopause, is seldom mentioned in law and public policy. This political silence on menstruation can, in part, be explained by the shame associated with menstruation. Menstrual shame has its origins in menstrual taboo in many religions and is undoubtedly present in Western culture. ${ }^{6}$ In societies where

1 Amy Remeikis and Paul Karp, 'Tampon Tax to Go as Treasurers Finally Agree to GST Exemption', The Guardian (online), 3 October $2018<$ https:/www.theguardian.com/australia-news/2018/oct/03/ tampon-tax-to-go-as-treasurers-finally-agree-to-gst-exemption>.

2 Particularly in the United States ('US'), menstruation has become such a mainstream issue in the media through activism focused on issues such as tampon taxes and product safety, that 2015 was declared 'the year of the period' by National Public Radio and Cosmopolitan: Anna Maltby, 'The 8 Greatest Menstrual Moments of 2015', Cosmopolitan (online), 13 October $2015<\mathrm{https}$ :/www.cosmopolitan.com/ health-fitness/news/a47609/2015-the-year-the-period-went-public>; Malaka Gharib, 'Why 2015 Was The Year of the Period, and We Don't Mean Punctuation', National Public Radio (online), 31 December $2015<$ https://www.npr.org/sections/health-shots/2015/12/31/460726461/why-2015-was-the-year-ofthe-period-and-we-dont-mean-punctuation>. See also Abigail Jones, 'The Fight to End Period Shaming is Going Mainstream', Newsweek Magazine (online), 20 April $2016<\mathrm{https} / /$ www.newsweek.com/ 2016/04/29/womens-periods-menstruation-tampons-pads-449833.html>.

3 See, eg, Amanda Klasing, 'Why Menstrual Hygiene is an Urgent Human Rights Issue', Human Rights Watch (online), 22 March $2018<$ https:/www.hrw.org/news/2018/03/22/why-menstrualhygiene-urgent-human-rights-issue $>$. See also Human Rights Watch and WASH United, Understanding Menstrual Hygiene Management and Human Rights (Report, August 2017) $<$ https://www.hrw.org/sites/default/files/news_attachments/mhm_practitioner_guide_web.pdf $>$.

4 Including Chris Bobel et al (eds), The Palgrave Handbook of Critical Menstrual Studies (Palgrave, forthcoming): see 'The Palgrave Handbook of Critical Menstrual Studies - Call for Ideas, Inputs \& Suggested Chapters', Menstrual Hygiene Day (Web Page, 2017) <http://menstrualhygieneday.org/ palgrave-handbook-critical-menstrual-studies-call-ideas-inputs-suggested-chapters $>$. Recent articles on menstruation, law and rights include: Inga T Winkler and Virginia Roaf, 'Taking the Bloody Linen Out of the Closet: Menstrual Hygiene as a Priority for Achieving Gender Equality' (2015) 21(1) Cardozo Journal of Law and Gender 1; Bridget J Crawford and Carla Spivack, 'Tampon Taxes, Discrimination, and Human Rights' [2017] (3) Wisconsin Law Review 491; Abigail Durkin, 'Profitable Menstruation: How the Cost of Feminine Hygiene Products is a Battle Against Reproductive Justice' (2017) 18(1) Georgetown Journal of Gender and the Law 131.

5 The article will examine inequality related to menstruation in the Australian context and will also draw on comparative examples and responses.

6 Thomas Buckley and Alma Gottlieb (eds), Blood Magic: The Anthropology of Menstruation (University of California Press, 1988); Sophie Laws, Issues of Blood: The Politics of Menstruation 
growing openness in dress and behaviour by women is tolerated, menstruation remains an issue requiring discreet and euphemistic mention if spoken of at all. ${ }^{7}$ Menstrual products, problematically termed 'feminine hygiene ${ }^{8}$ products, make no reference to periods or blood and are promoted for their invisibility and capacity to prevent 'accidents', embarrassment and distress. ${ }^{9}$ When tampons are advertised they are often dyed with blue ink to show absorbency rather than the actual colour of blood since real bodily fluids are deemed too confronting. ${ }^{10}$ When women's bodily functions are 'unseen', it is not surprising that these functions are equally invisible in law. This article considers how legal responses to marginalisation related to menstruation can challenge stigma and silence that operate to reinforce gender inequality.

The failure to fully acknowledge women's physical reality has a range of serious impacts alongside experiences of shame. For example, period pain may affect women's employment, and menstruation may result in missed schooling. This article will discuss the multidimensional nature of inequality that arises in relation to menstruation. It will also consider the intersectional discrimination that occurs in relation to menstruation facing different groups of women: for example, where lack of menstrual self-management is used as a reason to sterilise girls and women with disabilities without their consent. Intersectional discrimination occurs where a combination of attributes generates a new form of discrimination affecting people at

(Macmillan, 1990); Victoria Newton, Everyday Discourses of Menstruation: Cultural and Social Perspectives (Palgrave Macmillan, 2016).

7 See the following article, which originally appeared in the October 1978 issue of Ms. Magazine: Gloria Steinem, 'If Men Could Menstruate' in Outrageous Acts and Everyday Rebellions (Open Road Media, $2^{\text {nd }}$ ed, 2012) 718. See also Rose George, 'What if Men Had Periods? It's a Question Still Worth Posing', The Guardian (online), 29 May $2015<\mathrm{https}$ :/www.theguardian.com/commentisfree/ 2015/may/28/what-if-men-had-periods $>$. This silence also has profound impacts on women's health: Clementine Ford, 'Why is it So Hard to Believe a Woman in Pain?', The Sydney Morning Herald (online), 5 April $2018<$ https:/www.smh.com.au/lifestyle/health-and-wellness/why-is-it-so-hard-tobelieve-a-woman-in-pain-20180405-p4z7zb.html>.

8 Przybylo and Fahs note that " $[\mathrm{t}]$ he phrase feminine hygiene - a relic from 1930s advertisements for birth control - emphasizes the dirtiness of menstrual bleeding and the aspirational "cleanliness" women can have when using certain products while also rendering menstrual bleeding a unilaterally feminine experience': see Ela Przybylo and Breanne Fahs, 'Feels and Flows: On the Realness of Menstrual Pain and Cripping Menstrual Chronicity' (2018) 30(1) Feminist Formations 206, 211 (emphasis in original, citations omitted). Note also the preliminary suggestions by Park of the racial underpinnings of 'female hygiene': see Shelley M Park, 'From Sanitation to Liberation?: The Modern and Postmodern Marketing of Menstrual Products' (1996) 30(2) Journal of Popular Culture $149,166 \mathrm{n} 1$.

9 Though note some shifts in advertising these products in response to activism: Camilla Mørk Røstvik, 'Adventures in Menstruation: How Period Product Ads Have Changed to Reflect a More Realistic Experience for Women', The Conversation (online), 9 March $2018<\mathrm{https}$ ://theconversation.com/ adventures-in-menstruation-how-period-product-ads-have-changed-to-reflect-a-more-realisticexperience-for-women-91417>.

10 Winkler and Roaf (n 4) 6. See, eg, Chella Quint's STAINS ${ }^{\mathrm{TM}}$ artwork:

STAINSTM is a spoof aspirational brand. It is a line of bloodstain-themed fashions and accessories. ... STAINS ${ }^{\text {TM }}$ critiques disposable menstrual product advertising's lack of engagement with blood, except for when they use 'leakage fear' and words like 'whisper' and 'discreet' to shame consumers into seeking out their innovations.

'STAINS ${ }^{\mathrm{TM}}$, Dublin Science Gallery (Web Page) <https://dublin.sciencegallery.com/blood/stains>.

See also Period Positive, 'Welcome to \#periodpositive', Period Positive (Web Page) $<\mathrm{http}: / /$ www.periodpositive.com/>. 
the intersection of these. ${ }^{11}$ For example, while all women can experience sex discrimination and all black people can experience race discrimination, black women might experience discrimination at the intersection of sex and race, not experienced by white women or black men. The intersectional discrimination experienced by black women might be overlooked if there is a narrow focus on sex discrimination based only on the experiences of white women. The need to understand discrimination related to menstruation intersectionally also requires a focus on groups other than women. Although challenges to the problematic treatment of menstruation in society have been raised primarily by feminists in relation to women's bodies, the issue does not only affect cisgender women. Transgender, gender-diverse and intersex people may also experience discrimination related to menstruation. The article will consider how expanded understandings of sex and gender discrimination need to inform and reshape legal responses.

The article begins by drawing on feminist theories of the body and law to explain why menstruation produces legal silence and generates inequality (Part II). It applies equality theory to understand how treatment of menstruation leads to gender inequality (Part III). The article then considers the possible role of discrimination law in addressing discrimination related to menstruation and the limits of Australian law in responding to some forms of inequality arising from menstruation (Part IV). It goes on to explore menstruation as an intersectional issue through a focus on discrimination as it affects women with disabilities, incarcerated women and transgender, gender-diverse and intersex people (Part V). The concluding section argues that inequality related to menstruation is a multifaceted problem requiring creative use of existing law and new legal responses to achieve reproductive and social justice (Part VI). It identifies menstruation as an underexamined subject of discrimination law and feminist legal theory, and suggests some avenues for development of the law and its application.

\section{The Menstruating Body and Law}

Feminist legal scholarship contains longstanding, diverse and lively debates on relationships between women's bodies, law and gender inequality. For some feminist legal scholars, this inequality relates to law's reliance on medical knowledge to pathologise women's bodies and to mask interventions in and control of women's bodies as apolitical, therapeutic and beneficial. ${ }^{12}$ For other feminist legal scholars, the focus is on law's role in inhibiting women's capacity to exercise autonomy over their bodies through, for example, limiting lawful access to abortion. ${ }^{13}$ Reproductive justice scholars (who do not focus specifically on law) see women's reproduction as a key vehicle through which individual women and entire marginalised populations are oppressed. These scholars draw connections between different aspects of regulation of reproduction and family, and also draw connections

11 Kimberle Crenshaw, 'Demarginalizing the Intersection of Race and Sex: A Black Feminist Critique of Antidiscrimination Doctrine, Feminist Theory and Antiracist Politics' [1989] University of Chicago Legal Forum 139.

12 See, eg, Carol Smart, Feminism and the Power of Law (Routledge, 1989) 90-113.

13 See, eg, Catharine A MacKinnon, Feminism Unmodified: Discourses on Life and Law (Cambridge University Press, 1987) ch 8 ('Privacy v Equality: Beyond Roe v Wade'). 
across structural dynamics such as eugenics, colonialism and neoliberalism. ${ }^{14}$ Across these approaches, there is recognition of the contradictions and complexities in law's role in sustaining gender inequality - law sometimes exposes and removes privacy and dignity from women and, at other times, silences, hides and shames. This scholarship provides important insights into the possibilities and limitations of discrimination law in both responding to and possibly reifying inequalities arising from menstruation.

Complementing the feminist legal scholarship is feminist scholarship on women's bodies. Some feminists have argued that women's bodies are positioned as 'deviant' against the 'norm' of the male body. ${ }^{15}$ They have argued that the body is a site of discipline and normalisation. ${ }^{16}$ Problematising, and consequently intervening in, specific bodily processes that are gendered female is a means of broader social control of women and maintenance of gender (and other) hierarchies. ${ }^{17}$ Medicalisation is a key process through which this disciplining and normalisation of female bodies occurs. Shildrick argues that a medical model of the body is culturally dominant. ${ }^{18}$ In this model, there is a clear split between body and mind such that 'the knowing subject is disembodied, detached from corporeal raw material'. ${ }^{19}$ This medical model of the body is gendered with women 'being somehow more fully embodied than men'. ${ }^{20}$ Female embodiment is constructed as 'leaky' by reason of such processes as menstruation, lactation and childbirth that reflect the inability of the female body to meet the norm of the idealised 'bounded' and closed male body. Shildrick argues that through menstruation 'women, unlike the self-contained and self-containing man, leaked', thus reflecting the unbounded and open nature of the female body. ${ }^{21}$ Shildrick observes a paradox that 'while women are represented as more wholly embodied than men, that embodiment is never complete nor secure' ${ }^{22}$ Instead, male bodies are constructed as possessing the boundaries that provide for normative selfhood of the knowing (male) subject. Female bodily processes, and women more generally, are excluded both culturally and materially, in order to protect the norm of male embodiment. Exclusion occurs through medical processes of surveillance, diagnosis and treatment. These medical processes provide an 'objective', scientific framework for measuring women's embodiment against male norms and a basis for imposing expectations on women to self-regulate their bodies or, failing their ability to do so, rationalises interventions

14 See, eg, Loretta Ross et al (eds), Radical Reproductive Justice: Foundations, Theory, Practice, Critique (Feminist Press at CUNY, 2017); Rickie Solinger and Loretta J Ross, Reproductive Justice: An Introduction (University of California Press, 2017).

15 Elizabeth Arveda Kissling, Capitalizing on the Curse: The Business of Menstruation (Lynne Rienner Publishers, 2006) 3-5.

16 Sandra Lee Bartky, 'Foucault, Femininity, and the Modernization of Patriarchal Power' in Claudia Malacrida and Jacqueline Low (eds), Sociology of the Body: A Reader (Oxford University Press, 2016) ch 2 .

17 Linda Steele, Macarena Iribarne and Rachel Carr, 'Medical Bodies: Gender, Justice and Medicine' (2016) 31(88) Australian Feminist Studies 117.

18 Margrit Shildrick, Leaky Bodies and Boundaries: Feminism, Postmodernism and (Bio)ethics (Routledge, 1997).

19 Ibid 13-14.

20 Ibid 26

21 Ibid 34.

22 Ibid 35 
by others. ${ }^{23}$ Shildrick's scholarship suggests that female embodiment, the female body and female bodily processes are key sites for grounding women's inequality, and that it is vital to consider whether discrimination law can respond to gender inequality arising from these sites.

Turning specifically to menstruation, critical menstrual scholars have argued that menstruation and the menstruating body are central to women's inequality. Bobel argues that menstruation is 'constituted as a problem in need of a solution', ${ }^{24}$ resulting in the individual discipline and collective regulation of women. ${ }^{25}$ Shail and Howie propose that menstrual discourse has been a key means through which gendered difference and maleness have been constructed, ${ }^{26}$ and menstruation 'serves to provisionalise the inclusion, as human, of the female-embodied' ${ }^{27}$ They suggest that menstruation is a key way through which 'concessions of pre-discursive [ie 'natural' or 'apolitical'] sex difference are often made'. ${ }^{28}$ There is a core contradiction inherent in the gendering of menstruation - Winkler and Roaf note that while menstruation is 'an integral part of female identity', 'it goes against "feminine" attributes, by being bloody, smelly, and natural' ${ }^{29}$ In a similar vein, Przybylo and Fahs have noted that '[p]ervasive cultural messages of menstruation and the menstruating body as gross, disgusting, or shameful have created a dominant narrative of menstruation as a negative, troubling, problematic experience for those who menstruate ${ }^{30}$ and that menstrual blood 'necessitates containment and sanitization'. ${ }^{31}$ They argue that menstruation is a cultural signifier of the disordered, pathological and dangerous state of the female body. ${ }^{32}$ Societal responses to menstruation also enforce gendered spatial ordering and male privilege. For example, O'Keefe notes that 'women's ability to menstruate is used as a justification for the creation and continuation of the public/private divide'. ${ }^{33}$ Feminist theories of the body read together with scholarship on menstruation demonstrate that menstruation, a source of shame, disgust and abjection, is a basis for gender inequality.

Some critical menstruation scholars have highlighted the need for a nuanced understanding of menstruation and gender inequality, which takes account of other political dynamics such as colonialism, imperialism and racial oppression and is mindful that not all women will experience the same kinds or degrees of inequality by reason of their menstruation. For example, Koja-Moolji and Ohito argue that the particular concern around menstrual 'hygiene' and girls in developing countries relates to 'the leakages of [Black and Brown] bodies constitut[ing] a threat to the

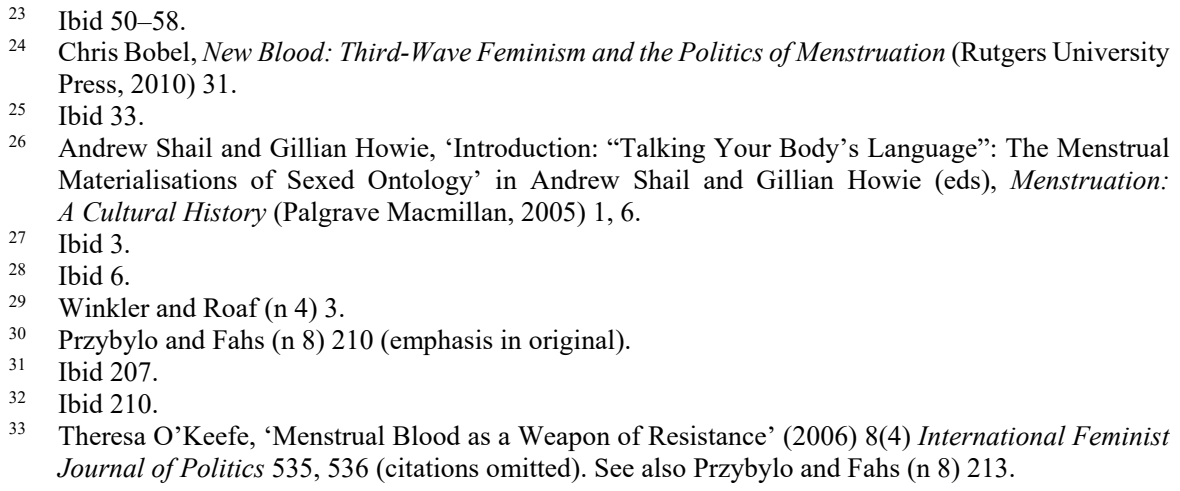


developed, civilized, modern White body, which is the manifestation of civilization and, hence, a target for protective custody'. ${ }^{34}$ Thus, they argue that

the anxieties around the periods and menstruation practices of girls in the global South [is] not just a health concern but also an effort to isolate Black and Brown bodies from 'leaking' into whiteness as personified by the Western (wo)man, who is regarded as the human rather than a type of human. ${ }^{35}$

Koja-Moolji and Ohito's development of Shildrick's theory draws attention to the need to think about menstruation, gender inequality and discrimination law in colonial, racial and geopolitical contexts and to be mindful of the particularities of inequality in relation to different groups. We draw further on these ideas in our discussion of intersectionality below when we explore menstruation, gender inequality and discrimination law in the contexts of certain marginalised groups. Ultimately, this scholarship suggests the need to question the extent to which Australian discrimination law reduces, or instead reifies, inequalities between women, including whether it can respond to intersectional and structural forms of discrimination that might be experienced by particularly marginalised populations. The feminist legal theory and broader feminist theory discussed above concerning the treatment of women's bodies provides a conceptual framework for our understanding of menstruation as an equality issue and provides a critical basis for exploring the role of law and discrimination law, in particular, in addressing inequalities related to menstruation.

\section{Menstruation and Inequality}

The principle of equality of men and women that underlies prohibitions against sex discrimination is internationally acknowledged and specifically recognised in Australian law. ${ }^{36}$ In pursuit of this principle, feminists have successfully fought for the removal of legal barriers facing women such as the right to vote or enter certain professions. This 'formal equality', treating likes alike, remains important where laws are overtly discriminatory on the basis of sex. However, despite the removal of such laws, gender inequalities persist: for example, where women continue to accrue smaller superannuation balances due to time spent on unpaid care of children or where women make up a minority of members of parliament because they are not selected within political parties. Thus, without measures to address underlying inequalities, full equality will not be achieved. It has therefore been recognised in international law that equality must go beyond formal neutrality and must be 'substantive', whether through different treatment or challenging and transforming barriers. ${ }^{37}$ The United Nations' Committee on the Elimination of Discrimination

34 Shenila Khoja-Moolji and Esther O Ohito, 'Containing the Leakiness of Impure Inhumans: Bleeding Third-World Bodies and the Confining Politics of Menstrual Hygiene Campaigns' in Susan Talburt (ed), Youth Sexualities: Public Feelings and Contemporary Politics (ABC-CLIO 2018) vol 1, 107, 109.

35 Ibid 109 (emphasis in original) (citations omitted). On the dehumanisation through 'disposability' of racialised women, see also Sherene Razack, 'Gendering Disposability' (2016) 28(2) Canadian Journal of Women and Law 285, 296-302.

36 Sex Discrimination Act 1984 (Cth) s 3(d).

37 For example, the Committee on Economic, Social and Cultural Rights has interpreted the International Covenant on Economic, Social and Cultural Rights as follows: 
against Women, in interpreting the Convention on the Elimination of All Forms of Discrimination against Women ${ }^{38}$ has stated that:

The position of women will not be improved as long as the underlying causes of discrimination against women, and of their inequality, are not effectively addressed. The lives of women and men must be considered in a contextual way, and measures adopted towards a real transformation of opportunities, institutions and systems so that they are no longer grounded in historically determined male paradigms of power and life patterns. ${ }^{39}$

This far-reaching idea of equality requires a deep understanding of the context and history of inequality and the structural patterns that underlie it. Measures targeted at rectifying this complex inequality must go beyond superficial changes to ensure fundamental social reordering.

The development of a substantive idea of equality in response to the failings of earlier formal approaches has led scholars to propose a broader set of aims for legal measures to overcome inequality. Fredman has formulated a multi-dimensional approach to equality including distribution, recognition, participation and transformation. ${ }^{40}$ Measures to address inequality must overcome material and social disadvantage (distributive wrongs). They must also address stigma, stereotyping, humiliation and violence (recognition wrongs). In addition, they must promote the full and equal participation of those affected by discrimination. Lastly, they must be transformative in ensuring that structural change results for affected groups. This expansive notion of equality is a useful frame within which to consider how law might respond to inequality related to menstruation. It also helps to analyse the ways in which inequality related to menstruation manifest in society by looking at failures of distribution, recognition and participation and the structural factors that enable these failures.

Distributive inequality related to menstruation leads to gender disadvantage. Research with Indigenous Australian community organisations found that girls are missing school during menstruation because schools lack adequate facilities

Formal equality assumes that equality is achieved if a law or policy treats men and women in a neutral manner. Substantive equality is concerned, in addition, with the effects of laws, policies and practices and with ensuring that they do not maintain, but rather alleviate, the inherent disadvantage that particular groups experience.

Committee on Economic, Social and Cultural Rights, General Comment No 16: The Equal Right of Men and Women to the Enjoyment of All Economic, Social and Cultural Rights, $34^{\text {th }}$ sess, UN Doc E/C 12/2005/4 (11 August 2005) 2 [7].

38 Opened for signature 18 December 1979, GA Res 34/180, UN Doc A/RES/34/180 (entered into force 3 September 1981) annex.

39 Committee on the Elimination of Discrimination against Women, General Recommendation No 25, on Article 4, Paragraph 1, of the Convention on the Elimination of All Forms of Discrimination against Women, on Temporary Special Measures, UN GAOR, 30 ${ }^{\text {th }}$ sess, UN Doc A/59/38 (2004) pt one annex I [10].

40 Sandra Fredman, Discrimination Law (Oxford University Press, $2^{\text {nd }}$ ed, 2011) 25-33; Sandra Fredman and Beth Goldblatt, 'Gender Equality and Human Rights: For Progress of the World's Women 2015-2016' (Discussion Paper No 4, UN Women, 2015) 1-56<https://www.unwomen.org//media/headquarters/attachments/sections/library/publications/2015/goldblatt-fin.pdf?la=en\&vs=16 $27 \& l a=$ en\&vs $=1627>$. For an application of Fredman's approach to menstrual hygiene, see Virginia Roaf and Inga Winkler, 'Menstrual Hygiene - The Bloody Road to Substantive Equality', Oxford Human Rights Hub Blog (Blog Post, 26 May 2015) < http://ohrh.law.ox.ac.uk/menstrual-hygiene-thebloody-road-to-substantive-equality/>. 
including soap and bins alongside running water, toilets that flush and privacy. ${ }^{41}$ Poverty in some remote communities is exacerbated by the excessive cost of basic products, such as menstrual pads, which can be well above the prices charged in cities. $^{42}$

Recognition wrongs can result from attitudes and practices that cause stigma and stereotype menstruating women and girls. ${ }^{43}$ For example, menstruation has been used as an argument by opponents of women being allowed to enter combat roles in the military. ${ }^{44}$ Humiliation and loss of dignity can result from the failure to address the needs of menstruating women. Refugees and migrant women have talked about girls hiding their periods due to shame and parents' unwillingness to discuss menarche, the first occurrence of menstruation, due to embarrassment. ${ }^{45}$ These attitudes may act as barriers to prevent women and girls from accessing reproductive health services. ${ }^{46}$

Understanding inequality related to menstruation requires a close attention to behaviours, perceptions and meanings at the individual level, as well as at the broader systemic level, taking account of historical factors, social and cultural attitudes and economic and political forces. ${ }^{47}$ Thus, discrimination causing shame and discomfort due to the lack of a bin in a toilet is also about the failure to consider the needs of girls in designing education facilities. This may be more broadly connected to poor conditions in remote, Indigenous communities in a country where colonialism, racism and patriarchy have shaped access to schooling. Similarly, failure to take account of the different cultural and linguistic backgrounds of members of the community in service design may lead to inadequate amelioration of practices that cause distress and shame.

The distributive and recognition dimensions of inequality related to menstruation arise in both developed and developing country contexts. They concern access to work, education, housing and many other areas of life impacted by resourcing, poverty and inadequate or inappropriate provision of facilities. Lack of

41 Nina Hall et al, 'Water, Sanitation and Hygiene in Remote Indigenous Australia: A Scan of Priorities' (Discussion Paper, University of Queensland Global Change Institute, July 2017) 38-9 $<$ https:/gci.uq.edu.au/filething/get/13903/UQ_WASH\%20scan\%20in\%20Indig\%20CommunitiesFINAL-LR-2.pdf>.

42 Ibid 39. Shame and taboo emanating from culture may, of course, also combine with these material contributors to girls missing school.

43 Many religions place restrictions on menstruating women that limit their participation in religious and cultural practices, as well as daily activities. While these issues inform the argument being made here, a deeper consideration of their dimensions and legal implications are beyond the scope of this article.

44 Anne Summers, 'The Lady Killers: Women in the Military', The Monthly (online), Dec 2011-Jan 2012 $<$ https://www.themonthly.com.au/issue/2011/december/1322725684/anne-summers/lady-killers>.

45 Jane M Ussher et al, 'Negotiating Discourses of Shame, Secrecy, and Silence: Migrant and Refugee Women's Experiences of Sexual Embodiment' (2017) 46(7) Archives of Sexual Behavior 1901, 1908-9. However, this shame is not limited to migrant and refugee communities. Pascoe argues that menstrual taboos continue to affect Australian women as a whole: see Carla Pascoe, 'The Ongoing Taboo of Menstruation in Australia', The Conversation (online), 3 February 2016 $<$ https://theconversation.com/the-ongoing-taboo-of-menstruation-in-australia-53984>.

46 Ussher et al (n 45) 1917.

47 See generally, Colleen Sheppard, Inclusive Equality: The Relational Dimensions of Systemic Discrimination in Canada (McGill-Queen's University Press, 2010). 
adequate sanitation and hygiene in particular is a significant barrier to schooling and public participation. ${ }^{48}$ It poses a serious challenge for homeless women, including in wealthier countries. Even where resources are available, the decision, for example, to provide toilet paper in public toilets, but not tampons or pads, suggests a failure to consider or accommodate the needs of women in public spaces. Issues of access as well as attitudes go hand in hand in causing exclusion, stigma and disadvantage.

Participation of affected groups is important in the design of initiatives to address inequality related to menstruation. Enabling the sharing of views by schoolgirls or women workers as to how they would like their schools or workplaces designed to accommodate their menstrual needs might lead to creative suggestions that school governing bodies or employers have not considered. The resulting policies and practices may prove more appropriate and may reflect the needs of different groups of women.

Being aware of differences between groups is crucial in efforts to address gender inequality, including in relation to menstruation. As will be discussed in more detail in Part V below, other forms of group-based discrimination such as race, age, class, or disability may operate together with gender to compound discrimination related to menstruation. For example, where poor women lack access to sanitation or menstrual products, they may have more regular experiences of shame and discomfort than their wealthier counterparts. Locational factors such as homelessness, incarceration or living in a remote area may also deepen disadvantage in relation to menstruation.

International responses to this inequality provide exemplars that Australia might follow. While removing the tampon tax is an important formal equality response to the lack of taxation attached to similar male products, a more targeted substantive equality response should address gendered disadvantage facing poor women. ${ }^{49}$ Scotland is the first country to provide free menstrual products to all students, both at schools and at tertiary institutions, in an effort to end "period poverty' ${ }^{50}$ New York City has introduced laws to provide menstrual products in public schools, shelters and prisons. ${ }^{51}$ Even in less wealthy countries such as India,

48 UN Special Rapporteur on the Human Right to Safe Drinking Water and Sanitation, Integrating Nondiscrimination and Equality into the Post-2015 Development Agenda for Water, Sanitation and Hygiene, UN GAOR, 67 ${ }^{\text {th }}$ sess, UN Doc A/67/270 (8 August 2012) 20 [73]-[74].

49 See Jessica Irvine, 'Why You Should Keep Paying the "Tampon Tax", The Sydney Morning Herald (online), 18 June $2018<$ https://www.smh.com.au/politics/federal/why-you-should-keep-paying-thetampon-tax-20180618-p4zm81.html>; Jessica Valenti, 'The Case for Free Tampons', The Guardian (online), 11 August $2014<$ https://www.theguardian.com/commentisfree/2014/aug/11/free-tamponscost-feminine-hygiene-products $>$.

50 Nadia Khomami, 'Scotland to Offer Free Sanitary Products to All Students in World First', The Guardian (online), 25 August $2018<$ https://www.theguardian.com/uk-news/2018/aug/24/scotlandto-offer-free-sanitary-products-to-all-students-in-world-first>.

51 Jennifer Weiss-Wolf, 'New York Makes History, with Tampons and Pads', The Opinion Pages: On The Ground (Blog Post, 21 June 2016) < https://kristof.blogs.nytimes.com/2016/06/21/new-yorkmakes-history-with-tampons-and-pads/>; Jennifer Weiss-Wolf, Periods Gone Public: Taking a Stand for Menstrual Equity (Arcade Publishing, 2017). Three local laws were introduced to amend the Administrative Code of the City of New York ('NYC Administrative Code'): (1) in relation to requiring that the Department of Correction issue feminine hygiene products to inmates: New York City Council Enactment No 2016/082, 13 July 2016 (adding a new \$9-141 to the NYC Administrative Code title 9 ch 1); (2) in relation to the provision of feminine hygiene products: New York City 
menstrual activism has led to legal change. In 2015, the High Court of Bombay recognised unequal and inadequate public provision of toilets as an equality violation in a decision requiring the municipal corporations within the State of Maharashtra to increase the number of public toilets for women in certain municipal areas and to include disposal facilities for menstrual products. ${ }^{52}$ These measures demonstrate a growing awareness that previous invisibility and inaction on the issue of menstruation has deepened vulnerability and hardship for certain groups of women and girls. Simply acknowledging that women menstruate by recognising that they need materials and product disposal facilities in public spaces beyond what is provided for the needs of men has transformative possibilities. It demonstrates that previous policies have been based on assumptions that the 'normal' user of public services is male, that equality may sometimes require different treatment, and that public expenditure may be required to remedy disadvantages that have historically been ignored. Such an acknowledgment may also contribute to more systemic change in attitudes to menstruation where, for example, the policy is broadcast publicly or where toilets become gender-neutral and men are exposed to the products and facilities usually used by women. Furthermore, it may overcome differences between women where homeless or indigent women are less able to attend to menstrual 'hygiene' than more advantaged women.

This discussion of inequality related to menstruation now leads to a consideration of the role of discrimination law — in particular what it might contribute and its limitations.

\section{Discrimination Related to Menstruation: Legal Possibilities and Limits}

Addressing inequality through law is a large project in which discrimination law is but one component. Discrimination law is used to prohibit certain conduct that is classified as discriminatory. Discrimination, like equality, is a contested and complex concept and choices over where to draw legal boundaries are rooted in political, historical and contextual considerations, and change over time. ${ }^{53}$ Australian law delineates the boundaries of what constitutes discrimination in a range of ways, including by attribute and how this is defined (such as sex, race, age, disability), and by scope or areas of life to which the law applies (such as work, education, services). In addition, a range of exceptions to prohibited discrimination are included in Australian discrimination laws. To add to the complexity, state ${ }^{54}$ and

Council, Enactment No 2016/083, 13 July 2016 (adding a new §12-207 to the NYC Administrative Code title $12 \mathrm{ch} \mathrm{2);} \mathrm{(3)} \mathrm{in} \mathrm{relation} \mathrm{to} \mathrm{the} \mathrm{provision} \mathrm{of} \mathrm{feminine} \mathrm{hygiene} \mathrm{products} \mathrm{in} \mathrm{schools:} \mathrm{New}$ York City Council, Enactment No 2016/084, 13 July 2016 (adding a new §21-968 to the NYC Administrative Code title 21-A ch 8).

52 Milun Saryajani Through Editor v Pune Municipal Commissioner (Unreported, High Court of Bombay, Civil Appellate Division, AS Poka and Revati Mohite Dere JJ, 23 December 2015) [17].

53 See generally Margaret Thornton, The Liberal Promise: Anti-Discrimination Legislation in Australia (Oxford University Press, 1990).

54 Anti-Discrimination Act 1977 (NSW); Equal Opportunity Act 1984 (SA); Equal Opportunity Act 1984 (WA); Anti-Discrimination Act 1991 (Q1d); Anti-Discrimination Act 1998 (Tas); Equal Opportunity Act 2010 (Vic). 
territory $^{55}$ discrimination laws sit alongside federal discrimination laws, ${ }^{56}$ and separate discrimination laws applying to the workplace. ${ }^{57}$

Discrimination related to menstruation is likely to be considered in terms of the attribute of 'sex' since it concerns a bodily process (usually) experienced by women. ${ }^{58}$ All Australian discrimination laws contain prohibitions against sex discrimination and discrimination based on a characteristic associated with a particular sex. ${ }^{59}$ There are many additional related attributes that are protected: some of which concern biological functions connected to sex including pregnancy and breastfeeding; others concerning social functions associated with gender such as family responsibilities and marital status; and a newer set of attributes relating to intersex status, gender identity and sexual orientation..$^{60}$ Discrimination related to menstruation may be likened to pregnancy and breastfeeding since it is a biological characteristic linked to female reproductive capacity, however it is not listed as an attribute in any Australian discrimination legislation nor has it been fully considered in any case law. ${ }^{61}$

While 'sex' is not defined in any Australian discrimination legislation, it has been interpreted by courts to include aspects of reproduction prior to the inclusion of these attributes in statutes. ${ }^{62}$ In the foundational case of Wardley $v$ Ansett Transport Industries, ${ }^{63}$ the Victorian Equal Opportunity Board found that a company policy to refuse to hire women pilots because of potential pregnancy and consequent maternity leave was sex discrimination. Notably, although the airline defended its policy on the basis of capacity for pregnancy, prior to the case the well-known conservative owner of the company, Sir Reg Ansett, had publicly aired his view that women's menstrual cycles made them unfit to be pilots. ${ }^{64}$ While the case took a broad approach to sex discrimination that avoided the problem, experienced elsewhere, of trying to find a male comparator for a pregnant female, subsequent cases have taken a narrower approach to the interpretation of sex discrimination outside of legislated attributes. ${ }^{65}$

55 Discrimination Act 1991 (ACT); Anti-Discrimination Act 1996 (NT).

56 Racial Discrimination Act 1975 (Cth); Sex Discrimination Act 1984 (Cth); Disability Discrimination Act 1992 (Cth); Age Discrimination Act 2004 (Cth).

57 Fair Work Act 2009 (Cth).

58 See discussion of people other than cisgender women who menstruate in Part V below. Menstruation beyond the 'normal' range of experience might also be considered a disability.

59 Sex Discrimination Act 1984 (Cth) s 5; Anti-Discrimination Act 1977 (NSW) s 24; Equal Opportunity Act 1984 (SA) s 29(2); Equal Opportunity Act 1984 (WA) s 8; Anti-Discrimination Act 1991 (Qld) s 7(a); Discrimination Act 1991 (ACT) s 7(1)(a); Anti-Discrimination Act 1996 (NT) s 19(1)(b); Anti-Discrimination Act 1998 (Tas) s 16(e); Equal Opportunity Act 2010 (Vic) s 6(o).

60 Beth Gaze and Belinda Smith, Equality and Discrimination Law in Australia: An Introduction (Cambridge University Press, 2017) 90-98; Neil Rees, Simon Rice and Dominique Allen, Australian Anti-Discrimination and Equal Opportunity Law (Federation Press, $3^{\text {rd }}$ ed, 2018) 292-331.

61 Note some mention of menstruation in New South Wales v Amery (2003) 129 IR 300, 302-3 [11]; Te Papa v Woolworths Ltd [2006] VCAT 1222 (3 March 2006) [14]; Watson v NSW BHP Steel Pty Ltd (1998) EOC 92-959, 78388-9 (concerning endometriosis).

62 Gaze and Smith (n 60) 92 n 9-5.

63 (1984) EOC 92-002.

64 Liz Porter, '25 Years On, Pilot Fighter Lands Softly', The Age (online), 27 June 2004 $<$ https://www.theage.com.au/articles/2004/06/26/1088145020233.html $>$.

65 Gaze and Smith (n 60) 81. 
This narrowing through the jurisprudence has been effected by the way the courts have understood the meaning of direct discrimination. Direct discrimination, as opposed to indirect discrimination, occurs where a person is treated less favourably than a comparable person in the same situation because of an attribute such as race or sex. Indirect discrimination occurs where a facially neutral rule leads to different outcomes due to a protected attribute. For example, a school that requires all students to participate in a swimming carnival without excusing girls who are menstruating is discriminating indirectly against the menstruating girls who might face punishment if they elect not to swim. A now unlikely example of direct discrimination might occur where a company explicitly chooses only to hire men or post-menopausal women because menstruating women are thought to be moody. However, discrimination related to menstruation is likely to manifest in less overt ways and it is here that the challenges of defining direct discrimination in our law become apparent.

Direct discrimination in relation to sex means less favourable treatment than a person of a different sex (the comparator) in the same circumstances. ${ }^{66}$ The High Court of Australia in the case of Purvis $v$ New South Wales (Department of Education and Training) ${ }^{67}$ created a hypothetical comparator to a child whose disability manifested as challenging behaviour - a badly behaved child without a disability. ${ }^{68}$ This led the Court to find that the child with a disability had not been discriminated against as the school would have responded in the same way to a child without a disability exhibiting similar behaviour. ${ }^{69}$ A more appropriate comparator would have been a child without a disability who was not poorly behaved since the complainant's behaviour was linked to his disability. By shifting and narrowing the imagined comparator, arguably the Court reduced the protections available to disadvantaged complainants. ${ }^{70}$ It is possible to imagine that in a case where an employer sanctions a female employee for working slowly due to tiredness from menstrual cramps, on the Purvis test, she would be compared to a man who behaves similarly but for other reasons, such as a hangover, rather than to a man who does not menstruate. ${ }^{71}$ Here, her behaviour is separated from her embodied reality, losing sight of the history and context of sex discrimination that attaches to women's bodies. This approach also adds a moral dimension by comparing her behaviour, which is not within her control, to the poor behaviour of the comparator, as was done in Purvis. This approach undermines the idea of accommodation, which requires employers and others to find ways of facilitating equal participation of the person in the workplace, school or other environment.

66 This is the usual formulation in legislation dealing with sex discrimination: see, eg, Sex Discrimination Act 1984 (Cth) s 5(1).

67 (2003) 217 CLR 92 ('Purvis').

68 Ibid 160-61 [223]-[225] (Gummow, Hayne and Heydon JJ); 100-02 [11]-[14] (Gleeson CJ), 173 [273] (Callinan J).

69 Ibid 101-2 [13]-[14] (Gleeson CJ).

70 Belinda Smith, 'From Wardley to Purvis: How Far Has Australian Anti-Discrimination Law Come in 30 Years?' (2008) 21(1) Australian Journal of Labour Law 3. But also note the view that the Purvis decision is more limited in its reach: Rees, Rice and Allen (n 60) 103-4.

71 Similar to the way the Federal Court of Australia in Thomson v Orica Australia Pty Ltd compared a woman demoted after taking maternity leave to a man who took extended leave rather than to a man who did not have to take maternity leave: (2002) 116 IR 186. 
This example raises some of the challenges of dealing with discrimination related to menstruation. Inappropriate legal responses can reinforce stereotypes of women as unreliable, disruptive or uncompliant. If menstruation is compared to illness this can have problematic consequences by medicalising a common physiological feature of women's lives. Medicalisation can also lead to protective responses that reinforce stereotypes of women as weak, incapable and deficient. While menstruation may co-exist with medical conditions such as endometriosis, in most cases period pain, ${ }^{72}$ heavy bleeding, tiredness and impact on mood are part of many women's normal experience of menstruation and should be recognised as a facet of female biology that needs to be accommodated by society. ${ }^{73}$ Instead, if discrimination law is poorly applied it can transform this routine experience into something abnormal and unsettling in contrast with a norm of the consistent, undisrupted or undisruptive male body. In so doing it can reinforce gender disadvantage. As O'Connell observes:

It is the stigmatised body that is made to 'wear' embodiment: the normalised body remains clean of bodily flaws and vulnerabilities. While acknowledging embodiment means that discrimination law is grounded in the reality of daily life, the one-sidedness of the acknowledgement reinscribes the relative privilege and disadvantage of the parties. ${ }^{74}$

The problematic outcome of comparing menstruation to illness is illustrated in the US case of Coleman $v$ Bobby Dodd Institute Inc ${ }^{75}$ In that case, a woman was warned and then dismissed from her job for accidentally bleeding on an office chair and then a carpet due to heavy pre-menopausal periods. The District Court of Georgia held that this did not constitute sex discrimination since the complainant did not allege that a man who soiled furniture due to incontinence would be treated better. ${ }^{76}$ The Court also said that menstruation was not a condition related to

72 Period pain is extremely common with 90 per cent of young women experiencing it monthly: Kathleen Calderwood, 'World's Largest Study into Period Pain to Help Women Understand What is Normal', $A B C$ News (online), 24 February $2018<$ http://www.abc.net.au/news/2018-02-24/period-pain-study-tohelp-women-know-whats-normal/9480042>; Mike Armour, Jane Chalmers and Melissa Parker, 'I Have Painful Periods, Could it be Endometriosis?', The Conversation (online), 29 August 2018 $<$ https://theconversation.com/i-have-painful-periods-could-it-be-endometriosis-101026>.

73 Peggy Maguire et al, 'Women and Menstruation in the EU' (Policy Brief, European Institute of Women's Health, 8 March 2018) <https:/eurohealth.ie/policy-brief-women-and-menstruation-inthe-eu/>. However, note Przybylo and Fahs who argue that absolute resistance to a medicalisation approach risks 'invisibilizing' and negating the real pain that some women experience in menstruation: Przybylo and Fahs (n 8).

74 Karen O'Connell, 'The Clean and Proper Body: Genetics, Stigma and Disability Discrimination Laws' (2009) 14(2) Australian Journal of Human Rights 139, 144.

75 (D Ga, Civ No 17-029, 8 June 2017). See also Jay-Anne B Casuga, 'Woman Fired Over Menstruation Settles Sex Discrimination Case', Bureau of National Affairs (online), 7 November 2017 $<$ https:/www.bna.com/woman-fired-menstruation-n73014471820/>; Elizabeth Segran, 'Bleeding On The Job: A Menstruation Investigation', Fast Company (online), 25 July 2016 $<$ https://www.fastcompany.com/3061417/bleeding-on-the-job-a-menstruation-investigation>; Kate Sedey, 'Court Holds Termination for Menstruation is Not Sex Discrimination. Seriously?', The Case Law Firm Blog (Blog Post, 25 August 2017) <https://www.thecaselawfirm.com/2017/08/25/courtholds-termination-menstruation-not-sex-discrimination-seriously/>.

76 See Coleman v Bobby Dodd Institute Inc (D Ga, Civ No 17-029, 8 June 2017). At [4], the Court did acknowledge the theoretical possibility of discrimination related to menstruation when it said:

Thus, a non-frivolous argument can be made that it is unlawful for an employer to treat a uniquely feminine condition, such as excessive menstruation, less favorably than similar 
pregnancy or childbirth, in distinguishing the case from one where a lactating woman had been successful in showing sex discrimination. The case illustrates the problem of the search for a hypothetical (ill) male comparator and the Court's inability to understand menstruation as a feature of female biology that should ground a claim for sex discrimination in its own right. The discussion here also raises complex questions worthy of future exploration about the strategic value and risks of aligning menstruation with illness, disability and medicalisation.

Menstruation may require accommodation in order to achieve substantive equality. It is important to find ways of making such accommodations that do not lead to protective responses that result in stereotyping and excluding women. This has been the challenge in relation to pregnancy discrimination. Protection of women's employment, their health and their reproductive rights in relation to pregnancy has been a long struggle in the workplace in many parts of the world. ${ }^{77}$ At the same time, protective responses have been used to prevent women from accessing certain occupations such as positions in the military and pilots due to their physical differences and reproductive capacity. Varied approaches to how pregnancy should be treated have been fought for in different jurisdictions. ${ }^{78}$ These differences reflect strategic responses to diverse anti-discrimination frameworks, but also raise important questions about how to understand sex and embodiment in ways that transform, rather than reinforce, harmful stereotyping and discriminatory responses. Addressing discrimination related to menstruation could involve specific measures such as menstruation leave, regulations allowing frequent bathroom breaks, or accommodations such as catch-up classes for girls who miss school due to menstruation-related conditions. At the same time, clear prohibitions against discrimination on the basis of menstruation are needed to ensure that women are not excluded from work, school or other institutions by those trying to avoid these measures and accommodations. The question of whether to make menstruation a defined attribute in discrimination law is ripe for future exploration.

The question of menstruation leave is an issue that raises challenges for equality law. In a number of Asian countries, including Taiwan, Indonesia, Japan and South Korea, women are entitled to such leave. ${ }^{79}$ It is likely not coincidental that some of these countries rate poorly in terms of gender equality performance, as their menstrual leave policies may reflect paternalistic attitudes towards women. In Italy, where such leave has recently been considered, there are concerns that it could be

conditions affecting both sexes, such as incontinence. But Coleman does not claim that her excessive menstruation was treated less favorably than similar conditions affecting both sexes. Rather, she argues that the fact that her termination would not have occurred but for a uniquely feminine condition is alone sufficient to show that she was terminated because of her sex. The Court disagrees.

77 Sandra Fredman, 'Reversing Roles: Bringing Men into the Frame' (2014) 10(4) International Journal of Law in Context 442; Alexandra Heron and Sara Charlesworth, 'Effective Protection of Pregnant Women at Work: Still Waiting for Delivery?' (2016) 29(1) Australian Journal of Labour Law 1. For a discussion of the US context, see Reva B Siegel, 'Pregnancy as a Normal Condition of Employment: Comparative and Role-Based Accounts of Discrimination' (2018) 59(3) William \& Mary Law Review 971.

78 Fredman (n 77).

79 Kuntala Lahiri-Dutt and Kathryn Robinson, "Period Problems" at the Coalface' (2008) 89(1) Feminist Review 102; Alice J Dan, 'The Law and Women's Bodies: The Case of Menstruation Leave in Japan' (1986) 7(1-2) Health Care for Women International 1. 
used by employers to reduce the number of women employed in a country that already has low female employment, and that it will contribute to stereotyping about women's emotions during menstruation. ${ }^{80}$ The existence of menstruation leave does not necessarily improve working conditions for women if women fear that using such leave will disadvantage their prospects of workplace advancement. At the same time, responses to leave may differ depending on the type of work women do since labourers may have greater need for such leave than office workers. ${ }^{81}$ The challenge in addressing menstruation in the workplace is therefore highly complex, as it might require accommodation, but this must avoid reinforcing stereotypes or increasing disadvantage.

Creative efforts to reimagine the workplace as a space that accommodates menstruation without this disadvantage are being trialled by the Victorian Women's Trust, which argues against labelling menstruation as an illness. The Trust encourages other employers to adopt their policy, which allows employees flexibility to do the following: work from home; 'stay in the workplace under circumstances which encourage the comfort of the employee eg. resting in a quiet area'; or take a day's paid leave (up to 12 per year). ${ }^{82}$ Other forms of accommodation could be considered in schools - for example, providing alternative exam dates for girls affected by period pain.

Where such efforts are not occurring, the Australian anti-discrimination framework offers some possibilities for women affected by discrimination related to menstruation to challenge unequal treatment. However, there are a number of wellworn concerns with the limits of this framework in addressing gender inequality. ${ }^{83}$ Discrimination law is focused on individual complaints and rarely results in systemic responses. Enforcement often results in settlements that are confidential, so most matters do not reach courts and hence lack a broader public impact. The law is largely reactive, rather than proactive, in identifying inequality and responding to it. While some efforts have been made to encourage affirmative action and positive measures in the workplace, ${ }^{84}$ these do not extend to other areas of society and have their own limitations. ${ }^{85}$ The lack of a general right to equality at the federal level and in most states and territories means that the scope and reach of anti-discrimination

80 Anna Momigliano, 'Italy Set to Offer "Menstrual Leave" for Female Workers', The Independent (online), 25 March $2017<$ https://www.independent.co.uk/news/world/europe/italy-menstrual-leavereproductive-health-women-employment-a7649636.html>; Sarah Wildman, 'Italy is Weighing a Law Granting Paid Leave for Women with Painful Periods', Vox (online), 29 March 2017 $<$ https:/www.vox.com/world/2017/3/29/15097842/menstruation-period-leave-italy-painfulcramps-women-maternity-blood $>$.

81 Lahiri-Dutt and Robinson (n 79).

82 Casimira Melican and Grace Mountford, 'Why We've Introduced a Menstrual Policy and You Should Too', Victorian Women's Trust Blog (Blog Post, 23 May 2017) < https://www.vwt.org.au/blogmenstrual-policy/>.

83 See Thornton (n 53); Dominique Allen, 'Rethinking the Australian Model of Promoting Gender Equality' in Kim Rubenstein and Katharine G Young (eds), The Public Law of Gender: From the Local to the Global (Cambridge University Press, 2016) 391; Beth Gaze, 'The Sex Discrimination Act at 25: Reflections on the Past, Present and Future' in Margaret Thornton (ed) Sex Discrimination in Uncertain Times (ANU Press, 2010), 107.

84 Through the Fair Work Act 2009 (Cth) and the Workplace Gender Equality Act 2012 (Cth).

85 See Allen (n 83). 
protection is somewhat limited. Legislative exemptions and court interpretations have further limited the reach of these laws.

An additional problem in some jurisdictions, built into the structure of separate discrimination laws dealing with different attributes, is the difficulty of bringing complaints based on discrimination that occurs at the intersection of two or more grounds. A woman facing discrimination related to menstruation must often choose whether to bring her claim as one of sex discrimination or instead based on age, disability, race, etc. However, in reality, human experience is not so neatly bounded and attributes may combine to compound discrimination or may lead to new forms of discrimination that do not affect people falling within a single attribute alone. Thus, using a single attribute model can lead to injustice. ${ }^{86}$ International law has overcome this problem by building in an understanding of intersectionality into its approach to substantive equality. ${ }^{87}$ Some countries have also found ways of addressing this in legislation or within their constitutional equality frameworks, ${ }^{88}$ but all Australian jurisdictions are yet to adopt this approach. The article now turns to a consideration of the ways in which intersectional inequality related to menstruation impacts on women with disabilities, incarcerated women and people who menstruate who do not identify as cisgender women. This demonstrates the need for discrimination law frameworks that are able to shift from narrow attributebased approaches to a broader and more substantive understanding of the purpose of discrimination law.

\section{Inequality Related to Menstruation at the Intersections}

Critical menstrual scholars have argued that gender inequality relating to menstruation is exacerbated for women who are positioned outside of normative constructs of the white, able, middle-class woman. ${ }^{89}$ For example, discrimination related to menstruation may arise in the unequal treatment of girls who have, or have not yet, begun menstruating (based on age or physical maturity); it may be targeted at women with disabilities who are seen as incapable of menstrual management; it may have a more extreme impact on women who are experiencing poverty or homelessness; ${ }^{90}$ and it may affect women in certain cultural or religious communities or geopolitical regions differently.

The differential forms and impacts of gender inequality related to menstruation are not accidental or incidental. Reproductive justice scholars and activists have long argued that women's enjoyment of bodily integrity and capacity to make choices concerning reproduction and parenting are shaped by dynamics of

Crenshaw (n 11).

Beth Goldblatt, 'Intersectionality in International Anti-Discrimination Law: Addressing Poverty in its Complexity' (2015) 21(1) Australian Journal of Human Rights 47.

88 See, eg, Canadian Human Rights Act, RSC 1985, c H-6, s 3.1; Constitution of the Republic of South Africa 1996 (South Africa) s 9(3).

89 See, eg, Khoja-Moolji and Ohito (n 34); Bobel (n 24) 28-41; Winkler and Roaf (n 4) 3-7.

90 In recognition of the impact of material inequalities on access to menstrual products and related physical mobility, the Australian organisation Share the Dignity works to provide sanitary products to homeless women and women seeking to leave domestic or family violence: Share the Dignity, Home Page (Web Page, 2019) < https://www.sharethedignity.com.au/>. 
systemic inequality. In particular, these relate to 'institutional forces such as racism, sexism, colonialism and poverty', ${ }^{91}$ as well as such factors as 'immigration status, ability, gender identity, carceral status, sexual orientation, and age'. ${ }^{22}$ In this respect, gender inequality related to menstruation needs to be understood through the prisms of intersecting dimensions of oppression and intersecting structural or institutional forces. These forces might be materially and legally disconnected or even irrelevant from the perspective of the inequality encountered by more privileged women.

When we use a more nuanced intersectional analysis and specifically interrogate gender inequality relating to menstruation for women who do not meet normative female gender roles, we find that this inequality manifests in very different ways that engage broader structural inequality (and structural violence). This article, in calling for more sustained scholarly engagement with menstruation, gender inequality and discrimination law, signals the need for caution in how this is approached so as not to reinstate the 'universalized [menstruating] woman'. ${ }^{33} \mathrm{We}$ now introduce empirical data on inequality related to menstruation as it relates to women with disabilities, incarcerated women, and transgender, gender-diverse and intersex people, and we question the extent to which Australian discrimination law can respond to these particular manifestations of inequality.

\section{A Women with Disabilities}

In a context where females are constructed as deficient vis-à-vis males, feminist disability scholars have argued that women and girls with disabilities are positioned against norms of the able female. This gives rise to greater degrees and different forms of discrimination, violence and marginalisation when compared to women and girls without disabilities. ${ }^{94}$ In relation to menstruation, women and girls with disabilities (and specifically women with cognitive impairments) are viewed as mentally and physically incapable of meeting gendered norms to conceal their menstrual blood and regulate their emotions purportedly associated with their menstrual cycle..$^{95}$ Noting menstruation's role in reproduction, these women and girls are also viewed as incapable of controlling their sexuality and managing their fertility. ${ }^{96}$ Additionally, menstruation and its signifying of sexuality and fertility is seen as placing women at greater risk of sexual abuse - or, rather, at greater risk of pregnancy from abuse, since removing the capacity to menstruate removes one of the signs of abuse, rather than the abuse itself. ${ }^{97}$ In being considered unable to selfmanage their bodily processes, women and girls with disabilities are consistently viewed as burdens on those who provide care to them. Menstruation is seen as an

Loretta J Ross, 'Reproductive Justice as Intersectional Feminist Activism' (2017) 19(3) Souls 286, 291.

Ibid.

Ibid 288.

94 Kim Q Hall, 'Reimagining Disability and Gender through Feminist Disability Studies: An Introduction' in Kim Q Hall (ed), Feminist Disability Studies (Indiana University Press, 2011) 1.

95 Linda Steele, 'Disability, Abnormality and Criminal Law: Sterilisation as Lawful and "Good" Violence' (2014) 23(3) Griffith Law Review 467; Linda Steele, 'Making Sense of the Family Court's Decisions on the Non-Therapeutic Sterilisation of Girls with Intellectual Disability' (2008) 22(1) Australian Journal of Family Law 1.

96 Steele, 'Disability, 'Abnormality and Criminal Law' (n 95).

97 Steele, 'Making Sense' (n 95). 
additional and superfluous source of labour and time for carers because often women and girls with disabilities are viewed as not needing menstruation for fertility reasons, ${ }^{98}$ reflecting the observation by Przybylo and Fahs that for women and girls with disabilities 'menstruation is seen as unnecessary, excessive, and tied to ableist reproductive hopes'.99

Research on women with intellectual disabilities has found that this group experiences difficulties and discrimination in relation to menstruation in a variety of ways. ${ }^{100}$ Women may not be given adequate information about menstruation or menstrual management because it is assumed they are incapable of understanding this information. In one study women with disabilities avoided discussing menstruation with men due to embarrassment and fear that by providing evidence of female bodily functions they might expose themselves to abuse. ${ }^{101}$ They also avoided requesting pain medication from carers, particularly men, and lacked control to self-medicate for menstrual pain. ${ }^{102}$ Women experienced embarrassment and fear due to internalised stigma when they felt they had created a 'mess' or failed to meet perceived menstrual 'etiquette'. ${ }^{103}$ Their experiences of menstruation were generally negative and disempowering and arguably to a greater extent than women without disability, since their bodies were so often subject to control and surveillance by carers and medical personnel. This assertion of control may result from the discomfort of society with seeing women with disabilities as adult women, as sexual and as fertile. ${ }^{104}$

Sterilisation is a particularly violent dimension of gender inequality related to menstruation for women and girls with disabilities. It is a surgical procedure that has historically been carried out as a form of eugenic social control on a diverse range of women deemed genetically unfit - for example, Indigenous women, poor women, incarcerated women, women with disabilities. In contemporary times, sterilisation has fallen out of favour as a systemic state-legislated process targeted at disabled, racialised, poor, migrant or incarcerated women. Yet, sterilisation is still legal in relation to a woman or girl with disabilities where it is perceived to be in such an individual's 'best interests'. In this context, courts play a key role in protecting women and girls with disabilities from arbitrary sterilisation through an

98 Alison Kafer, Feminist, Queer, Crip (Indiana University Press, 2013). Further research is needed to examine how shifting economic circumstances brought on by diverse dynamics including austerity politics (for example, in the UK and Canada) and marketisation and privatisation (for example, in Australia with the NDIS) impact on the 'management' of menstruation by disability services and families.

99 Przybylo and Fahs (n 8) 211.

100 Carol Hamilton, 'Sterilisation and Intellectually Disabled People in New Zealand-Still on the Agenda?' (2012) 7(2) Kōtuitui: New Zealand Journal of Social Sciences Online 61; Jackie Rodgers, 'Pain, Shame, Blood and Doctors: How Women with Learning Difficulties Experience Menstruation' (2001) 24(5) Women's Studies International Forum 523; Elizabeth Tilley et al, "The Silence is Roaring": Sterilization, Reproductive Rights and Women with Intellectual Disabilities' (2012) 27(3) Disability \& Society 413.

101 Rodgers (n 100) 529-30.

102 Ibid 526-7.

103 Ibid 530

104 Ibid 535. 
individualised justice approach. ${ }^{105}$ In Australia, parents of girls (under family law), guardians of women (under guardianship legislation) and doctors (under the doctrine of necessity) can make decisions to authorise sterilisation. Those who perform the sterilisation are protected from civil and criminal actions in assault, even though the woman or girl has not personally consented to the procedure. ${ }^{106}$

Where this sterilisation involves the removal of a women's uterus, it can be used to prevent women with disabilities from menstruating. ${ }^{107}$ In this 'progressive' era of sterilisation, menstruation has emerged as a basis on which sterilisation can be authorised. Since the 1980s, judicial decisions show that sterilisation has been used specifically to prevent menstruation by girls with disabilities for the purported benefit of the individuals themselves and their carers. Reasons include menstruation's impact on: quality of life (for example, ability to participate in education and social events, receive good quality care); behaviour (for example, distress and inability to cope with menstruation and 'poor hygiene practices'108) and existing health conditions (for example, hormonal impacts on epilepsy). ${ }^{109}$ Insofar as menstruation signals entry into womanhood, the lawfulness and social acceptance of sterilisation of girls with disabilities to prevent menstruation evidences legal and social discomfort with sexuality and disability because of infantilising of girls with disabilities as eternal children. ${ }^{110}$

The centrality of stigma associated with disability and menstruation is illuminated by Australian court decisions from the 1980s and 1990s relating to the power of the Family Court of Australia to authorise the sterilisation of girls with disabilities under its welfare jurisdiction. In one decision, the judge expressed the need to use sterilisation to avoid the 'frightening and unnecessary experience' of

105 Stephanie Ortoleva and Hope Lewis, 'Forgotten Sisters - A Report on Violence Against Women With Disabilities: An Overview of its Nature, Scope, Causes and Consequences' (Research Paper No 104, Violence Against Women With Disabilities Working Group, Women Enabled and Northeastern University School of Law, 21 August 2012) <https://repository.library.northeastern.edu/files/ neu:332599/fulltext.pdf> 41-4; Andreas Dimopoulos, Issues in Human Rights Protection of Intellectually Disabled Persons (Routledge, 2016) 163-71.

106 See, eg, Laura Elliott, 'Victims of Violence: The Forced Sterilisation of Women and Girls with Disabilities in Australia' (2017) 6(3) Laws, 7-8; Kirsty Keywood, 'Sterilising the Woman with Learning Difficulties - In Her Best Interests?' in Jo Bridgeman and Susan Millns (eds), Law and Body Politics: Regulating the Female Body (Dartmouth, 1995); Kirsty Keywood, "'I'd Rather Keep Him Chaste": Retelling the Story of Sterilisation, Learning Disability and (Non)Sexed Embodiment' (2001) 9(2) Feminist Legal Studies 185; Kristin Savell, 'Sex and the Sacred: Sterilization and Bodily Integrity in English and Canadian Law' (2004) 49(4) McGill Law Journal 1094; Steele, 'Disability, 'Abnormality and Criminal Law' (n 95); Steele, 'Making Sense' (n 95); Linda Steele, 'Temporality, Disability and Institutional Violence: Revisiting In Re F' (2017) 26(3) Griffith Law Review 378.

107 Carol Hamilton, 'Sterilization and Intellectually Disabled People in New Zealand: Rights, Responsibility and Wise Counsel Needed' (2017) 10(1) Kōtuitui: New Zealand Journal of Social Sciences Online 36, 36.

108 Steele, 'Making Sense' (n 95).

109 Ibid; Steele, 'Disability, 'Abnormality and Criminal Law' (n 95).

110 Steele, 'Making Sense' (n 95) 12-14. See generally Donna Bernert, 'Sexuality and Disability in the Lives of Women with Intellectual Disabilities' (2011) 29(2) Sexuality and Disability 129. This discomfort came into stark relief in the US context of 'Ashley X', where parents of a six year old girl with developmental disabilities had their daughter subjected to sterilisation, breast bud removal and hormone-related growth attenuation therapy. For a critical discussion of Ashley X, see Eva Feder Kittay, 'Forever Small: The Strange Case of Ashley X' (2011) 26(3) Hypatia 610; Alison Kafer, Feminist, Queer, Crip (Indiana University Press, 2013) 47-68. 
being in public with visible bleeding. ${ }^{111}$ In another case, the judge described sterilisation of a girl as 'lessen[ing] the physical burdens for the mother, in particular by decreasing the number of changes necessary in toileting'. ${ }^{112}$ Another judge dismissed a menstrual management education program as an alternative to sterilisation because his Honour considered it 'difficult to avoid the feeling, that here, perhaps too much reliance is being placed on the success of what are possibly imperfect programs, imperfectly administered and monitored upon, sadly, an imperfect subject'. ${ }^{113}$

The gender inequality arising from sterilisation is profound. There are risks and potential side effects associated with surgical procedures, as well as increased risk of some cancers. ${ }^{114}$ In addition, the peak body for Australian women with disabilities, Women with Disabilities Australia, state:

Forced sterilisation permanently robs women of their reproductive capacity, violates their physical integrity and bodily autonomy, and leads to profound and long-term physical and psychological effects, including: psychological pain, suffering, lifelong grief and trauma, extreme social isolation, family discord or breakdown, fear of medical professionals, social stigma, and shame. ${ }^{115}$

Women and girls who are sterilised become further entrenched as unequal to women without disabilities in being denied the choice to menstruate, to reproduce and to give birth to children. ${ }^{116}$

Recent government inquiries in Australia have suggested that the number of sterilisations has decreased. ${ }^{117}$ While this might suggest the practice is not as significant a concern in terms of gender inequality related to menstruation, instead we argue that it is for two reasons. First, there are no definitive statistics to confirm this decline in sterilisations and individuals may still have undergone procedures without seeking court authorisation. The laws permitting sterilisation still exist and recent government inquiries have resisted outlawing sterilisation ${ }^{118}$ and one even explicitly affirmed that sterilisation is non-discriminatory. ${ }^{119}$ Indeed, the Australian Government has considered sterilisation in the context of its inquiry into the family

111 Re Jane (1988) 12 Fam LR 662, 681 (Nicholson CJ).

112 Re Katie (1996) FLC 92-659, 82817 (Warnick J).

113 Re a Teenager (1988) 94 FLR 181, 190 (Cook J).

114 Australian Senate Community Affairs References Committee, Parliament of Australia, Involuntary or Coerced Sterilisation of People with Disabilities in Australia (Report, July 2013) 8.

115 Women With Disabilities Australia ('WWDA'), 'WWDA Position Statement 4: Sexual and Reproductive Rights' (Statement, September 2016) < http://wwda.org.au/wp-content/uploads/2016/ 10/Position_Statement_4_-_Sexual_and_Reproductive_Rights_FINAL_WEB.pdf $>10$.

116 Linda Steele, 'Court-Authorised Sterilisation and Human Rights: Inequality, Discrimination and Violence against Women and Girls with Disability?' (2016) 39(3) University of New South Wales Law Journal 1002, 1034.

117 See, eg, Diana Bryant AO, Submission No 36 to Senate Standing Committee on Community Affairs, Parliament of Australia, Inquiry into Involuntary or Coerced Sterilisation of People with Disabilities in Australia, February 2013.

118 Steele, 'Court-Authorised Sterilisation' (n 116). See, eg, Australian Senate Community Affairs References Committee (n 114); New South Wales Law Reform Commission, Review of the Guardianship Act 1987, Report 145 (2018).

119 Australian Senate Community Affairs References Committee (n 114). 92-4 [4.31]-[4.37]; 125-9 [5.100]-[5.112]. 
law system, suggesting this is a perennial issue that endures the scrutiny of law reform review. ${ }^{120}$ Second, any reduction in the number of sterilisations undertaken might be accompanied by an increased use of menstrual suppressing pharmaceuticals. ${ }^{121}$ In an Australian context, Women with Disabilities Australia has noted that ' $[\mathrm{t}]$ he use of menstrual suppressant drugs on girls and women with intellectual and/or cognitive impairment, particularly those in institutional and other closed settings, is widespread"122 and 'is rarely, if ever, subject to independent monitoring or review'. ${ }^{23}$ There is an argument that chemical forms of nonconsensual menstrual suppression are acceptable because they avoid the risks and harms of surgery. However, this overlooks that use of these pharmaceuticals is based on the same logic that menstruation is unnecessary, superfluous and burdensome for women and girls with disabilities and also ignores the fundamental denial of autonomy for women, while reaffirming stigma associated with menstruation.

Arguably non-consensual surgical intervention to prevent menstruation of women and girls with disabilities is an example of unequal treatment insofar as this would not be allowed in relation to women and girls without disabilities. While health services are covered by disability discrimination and sex discrimination legislation, one obstacle to making such a discrimination claim is the unhelpful case law on sterilisation of girls with disabilities. The cases have held that sterilisation under the Family Court of Australia's welfare jurisdiction is not discriminatory because there is no comparator to establish unfavourable treatment of women with disabilities. In the 1995 decision of $P v P,{ }^{124}$ the Full Court rejected the inclusion of a 'but for' question ('but for the disability, would this girl be sterilised?') in the best interests test for authorising sterilisation. The Court was of the view that while a 'but for' test might be 'superficially attractive' because it 'is non-discriminatory and equates the intellectually handicapped person with the non-intellectually handicapped', the test is 'conceptually incorrect'. ${ }^{125}$ It was deemed so because the Court found it was impossible to identify a comparator for such a test:

The Court's logic involved it being impossible to remove from Lessli the characteristic of her intellectual disability in order to determine whether she would still be sterilised without her disability. The core and necessary question of any discrimination inquiry - would this sterilisation be conducted if this individual was not disabled - could not be answered here because there was no way to comprehend Lessli existing as 'Lessli' without the disability. ${ }^{126}$

120 Australian Law Reform Commission, Review of the Family Law System (Issues Paper No 48, March 2018) 28 [75], 44-5 [134]-[135]. See a submission by one of the authors: Linda Steele, Submission No 211 to Australian Law Reform Commission, Review of the Family Law System (Issues Paper No 48, March 2018). The final report was released in 2019, but there is limited reference to the issue of sterilisation: Australian Law Reform Commission, Family Law for the Future - An Inquiry into the Family Law System (Report No 135, March 2019) 131 [4.70], 507 Question 9-1.

121 Australian Senate Community Affairs References Committee (n 114) 7.

122 Women With Disabilities Australia (n 115) 11.

123 Ibid 13.

124 (1995) 126 FLR 245.

125 Ibid 266-8.

126 Steele, 'Court-Authorised Sterilisation' (n 116) 1028. See further 1028-33. 
This legal position was approved in the recent Senate inquiry into involuntary or coerced sterilisation of people with disabilities in Australia. ${ }^{127}$ The Senate Committee recommended that sterilisation not be abolished, but instead be allowed to continue under a reformed test of 'best protection of human rights' (cf 'best interests'). The Committee agreed with the Family Court's reasoning on discrimination in $P v P$. The Committee was of the view that the 'best protection of rights' test would not extend to protection of rights to equality and nondiscrimination. ${ }^{128}$ This is not just a misguided understanding of disability discrimination law, but is also an example of the Court's inability to focus on two forms of discrimination at once (disability and sex) and their intersection. The absence of legal mechanisms for addressing intersectional discrimination, which emerges from this article's close analysis of menstrual inequality, is a key limitation with Australian discrimination law generally and has widespread ramifications for extremely marginalised populations in Australia.

\section{B Incarcerated Women}

There are different dynamics of gendered inequality in relation to menstruation for women who are incarcerated in prisons, policy custody, mental health facilities and immigration detention centres. As noted by reproductive justice scholars and activists, the dynamics of this inequality are situated in institutional dynamics of colonialism, neoliberalism and eugenics and can be inextricably linked to carceral circumstances such as control, degradation and humiliation. ${ }^{129}$

For example, Australian media ${ }^{130}$ recently reported on an Aboriginal woman in Western Australia being transported from a prison to a mental health facility in a state of distress, while naked and menstruating. ${ }^{131}$ The Sydney Morning Herald reported on an interview with a woman who had been in custody, who said that, '[i]n my experience, and other women's experience, [women] have asked repeatedly after six, 10, 12 hours for sanitary items and have not been getting them' and that 'the denial of sanitary items to women in holding cells can act as a power play for the officers in charge, particularly when they are dealing with inmates who are

27 Australian Senate Community Affairs References Committee (n 114).

128 Ibid 130-31. For a detailed critique, see Steele, 'Court-Authorised Sterilisation' (n 116).

129 Ross (n 91); Ross et al (n 14); Solinger and Ross (n 14).

130 For overseas examples, see Caroline Mortimer, 'Police "Routinely Ignoring” Needs of Female Detainees on Periods, Warns Watchdog', The Independent (online), 4 January $2018<\mathrm{https}$ :/www.independent.co.uk/ news/uk/crime/police-women-periods-ignore-needs-female-detainees-cctv-suspects-cells-arrest-tamponssanitary-a8141101.html>; Tamar Kraft-Stolar, 'Reproductive Injustice: The State of Reproductive Health Care for Women in New York State Prisons' (Report, Women in Prison Project of the Correctional Association of New York, 2015) <https://static.prisonpolicy.org/scans/Reproductive-Injustice-FULLREPORT-FINAL-2-11-15.pdf>; Durkin (n 4) 16; Tomi-Ann Roberts, 'Bleeding in Jail: Objectification, Self-Objectification and Menstrual Injustice' (2018), draft paper for submission to The Palgrave Handbook of Critical Menstrual Studies (Palgrave, forthcoming) (copy on file with authors).

131 Sarah Collard, 'Woman's Naked Prison Transfer Prompts Calls to Change System for Mentally Ill Inmates', $A B C$ News (online), 26 March $2018<$ http://www.abc.net.au/news/2018-03-26/nakedwoman-prison-transport-prompts-calls-to-change-system/9585380>. 
aggressive or experiencing drug induced psychosis'. ${ }^{132}$ In a 2017 report, the Northern Territory ('NT') Ombudsman noted that:

Many female prisoners said that while they were provided with very basic toiletries on induction and sanitary items are free, they are required to request in person for sanitary items from prison officers. The women advised that requesting sanitary items from a male prison officer is 'shame job' and not appropriate according to Indigenous culture. ${ }^{133}$

The Ombudsman went on to advise that:

Corrections should review its current procedure in relation to issuing sanitary items to female prisoners by a male prison officer and implement a procedure that will allow women prisoners to obtain sanitary items from female prison officers only or consider installing a sanitary vending machine at one or more locations within the female sector. ${ }^{134}$

There are also many documented examples in Australia of gender inequality in the context of strip searching of women who are menstruating. The trauma and violence associated with strip searching women in prison, particularly women who have themselves been victims of sexual assault, are well-known. ${ }^{135}$ However, what is perhaps less apparent is the significance of menstruation to the humiliation and degradation associated with strip searching. A number of Australian states and territories have published reports on strip searching, and some of these explicitly address menstruation issues. In 2002, a report by the then-Australian Human Rights and Equal Opportunity Commission cited women's prisoner activist Debbie Kilroy:

Indigenous women in Brisbane Women's Prison are subjected to a full strip search including cough and squat after every visit (family - legal). If the Indigenous woman is menstruating she is required to remove her tampon or pad and hand it to the screw [prisoner officer] for disposal. ${ }^{136}$

Kilroy noted the dilemma facing these women: 'They have to decide to be subjected to this indignity and sexual abuse in order to see their family or have legal counsel'. ${ }^{137}$ In a 2014 report devoted to strip searching at Townsville Women's Correctional Centre, the Queensland Ombudsman discussed an allegation that

132 Kate Bettes, 'Women Detainees Had to “Ask Repeatedly" for Sanitary Items', The Sydney Morning Herald (online), 15 February $2018<$ https:/www.smh.com.au/lifestyle/health-and-wellness/womendetainees-had-to-ask-repeatedly-for-sanitary-items-20180214-p4z0ca.html>.

133 Northern Territory Ombudsman, Investigation Report: Women in Prison II - Alice Springs Women's Correctional Facility (Report, May 2017) vol 2, $103<$ https://www.ombudsman.nt.gov.au/news/ women-prison-ii-investigation-report $>$.

134 Ibid vol 1, 62.

135 Mary Stathopoulos, ‘Addressing Women's Victimisation Histories in Custodial Settings' (Issues Paper No 13, Australian Centre for the Study of Sexual Assault, 2012) < https://aifs.gov.au/ sites/default/files/publication-documents/i13.pdf> 9-10. See also Women's Justice Network, 'Ceremonies of Degradation: Strip-searching in Women's Prisons A Policy Paper Regarding the Impacts of Strip-search Procedures on Women in Correctional Facilities' (Policy Paper Report, 15 April 2015) <https:/womensjusticenetwork.net.au/wp-content/uploads/2015/04/Strip-Searching-inWomens-Prisons-paper.pdf>; Anti-Discrimination Commission Queensland, 'Women in Prison' (Report, Anti-Discrimination Commission, March 2006) < https://www.adcq.qld.gov.au/_data/ assets/pdf file/0018/5148/WIP report.pdf> 72-3.

136 Human Rights and Equal Opportunity Commission, 'Indigenous Women and Corrections A Landscape of Risk' in Social Justice Report 2002, ch 5, 161; 205-208.

137 Ibid. This issue was again discussed in Anti-Discrimination Commission Queensland (n 135) 73. 
on occasion menstruating prisoners receiving ... medication were unable to access sanitary material between the first strip search (when they would be required to remove any sanitary pad) and the second strip search, and that prisoners found this humiliating.' 138

Menstrual inequality was also noted in the final report of the Royal Commission into the Protection and Detention of Children in the Northern Territory in the course of finding that '[f]emale detainees' needs relating to menstruation were not met at the former Don Dale Youth Detention Centre'. ${ }^{139}$ The report elaborated:

The special needs of females in detention include adequate provision and choice of sanitary products and open access to washing during menstruation. These special needs were not met and female detainees experienced humiliating and degrading treatment as a result.

At least at the former Don Dale Youth Detention Centre, female detainees were not permitted to keep sanitary products in their cells and were often required to ask male officers for them, with no choice of tampons or pads. Some girls were too embarrassed or ashamed to ask male officers for such items. AG said sometimes other girls would ask her to ask the male guards for them. Because the cells at the former Don Dale Youth Detention Centre did not have toilets or showers, females were also unable to go to the toilet or take a shower discreetly, without making a request of staff, if the need arose during menstruation. As recognised in NAAJA's submissions, it is 'completely culturally inappropriate for Aboriginal girls to have to speak about such matter[s] with male staff' ${ }^{140}$

Discrimination in these instances relates to sex, race, and location (incarceration). In addition, this discrimination is situated in structural inequality, since not all women have equal chances of being incarcerated. Women from marginalised population groups such as Aboriginal and Torres Strait Islander people, people with psychosocial and cognitive disabilities and people experiencing poverty have greater exposure to criminalisation and are particularly disadvantaged in the criminal justice system. ${ }^{141}$ Challenging such discrimination would be best achieved with legal responses that acknowledge intersectionality and structural discrimination - such ideas currently fall outside of Australian discrimination law.

These issues of menstruation-related discrimination against incarcerated women have also arisen in the context of Australian immigration detention. ${ }^{142} \mathrm{~A}$

138 Queensland Ombudsman, 'The Strip Searching of Female Prisoners Report: An Investigation into the Strip Search Practices at Townsville Women's Correctional Centre' (Report, September 2014) $<$ https://www.ombudsman.qld.gov.au/ArticleDocuments/239/The_strip_searching_of_female_prisi oners_report.pdf.aspx?Embed $=\mathrm{Y}>19$.

139 Royal Commission and Board of Inquiry into the Protection and Detention of Children in the Northern Territory (Final Report, November 2017) vol 2A, 450 ('NT Royal Commission Report').

140 Ibid 450 (emphasis in original).

141 Australian Law Reform Commission, Pathways to Justice - An Inquiry into the Incarceration Rate of Aboriginal and Torres Strait Islander Peoples (Report No 133, December 2017) 348 [11.6]; Eileen Baldry et al, A Predictable and Preventable Path: Aboriginal People with Mental and Cognitive Disabilities in the Criminal Justice System (IAMHDCD Report, University of New South Wales, 2015) 10, 37-43; Kat Armstrong, Eileen Baldry and Vicki Chartrand, 'Human Rights Abuses and Discrimination against Women in the Criminal Justice System in New South Wales' (2007) 12(2) Australian Journal of Human Rights 203, 205-8.

142 Overseas, issues of lack of access to sanitary products were raised in the context of the UK female immigration detention centre Yarl's Wood: Sarah Graham, 'This is the Trauma of Getting your 
2015 report of a Senate Committee inquiry into the Nauru Immigration Detention Centre noted that women had restricted access to sanitary products for security reasons. ${ }^{143}$ One reason offered for the lack of easy access to pads was that, "pads were a security hazard as they were allegedly soaked in gasoline during 2013 riots at the centre' (although Australian Greens Senator Hanson-Young noted there were no female detainees at the centre during the riots). ${ }^{144}$ Milanowicz, a former immigration caseworker for Hanson-Young, noted the humiliating situation of women in immigration detention having to line up for up to four hours to request pads from male guards. ${ }^{145}$ Paediatric nurse Alanna Maycock visited Manus Island on the invitation of International Health and Medical Services, which provided health services on the island. She recounted a story that was told to her:

One mother we met had been menstruating for around two months. She said she had reported this several times but had not been referred to a gynaecologist [sic] for review of her symptoms. She was using material from her tent to hold the bleeding because she didn't have free access to sanitary products. And one night the bleeding was so bad and she was extremely dirty, she decided to make the journey to the toilet. As she got near to the toilet where the male guards were sitting a blood clot fell from her to the ground. This women [sic] ran to the toilet as a trail of blood followed her. ${ }^{146}$

Discrimination law could be used responsively to achieve access to sanitary products for incarcerated women, who are generally from less financially privileged backgrounds and who face restricted provision of these products by the institutions themselves. ${ }^{147}$ Yet, addressing access must go beyond financial access and additionally take into account multidimensional inequalities encountered by women who are incarcerated. ${ }^{148}$ The participation of women in carceral settings is critical in ensuring that appropriate and transformative responses are developed to overcome this profound discrimination related to menstruation.

Arguably prison custody, correctional facilities, mental health facilities and onshore immigration detention centres would all be covered by state or territory and federal sex discrimination legislation insofar as these constitute 'services' or

Period at Yarl's Wood', The Femedic (online), 17 November $2017<$ https://thefemedic.com/ menstruation/the-trauma-of-getting-period-yarls-wood/>.

143 Australian Senate Select Committee on the Recent Allegations Relating to Conditions and Circumstances at the Regional Processing Centre in Nauru, Parliament of Australia, Final Report on Taking Responsibility: Conditions and Circumstances at Australia's Regional Processing Centre in Nauru (August 2015) 175-6.

144 Evidence to Senate Select Committee on the Recent Allegations Relating to Conditions and Circumstances at the Regional Processing Centre in Nauru, Parliament of Australia, Canberra, 19 May 2015, 41 (Mr John Rogers, Executive General Manager, Southern Pacific, Wilson Security).

145 Liberty Lawson, 'A Period in Detention', Honi Soit (online), 30 November 2015 $<$ http://honisoit.com/2015/11/a-period-in-detention/>. See also Wendy Syfret, 'For Asylum Seekers Menstruation is a Complicated and Often Humiliating Process', Vice (online), 9 October 2015 $<$ https://www.vice.com/en_au/article/ppxqv7/the-push-to-bring-menstrual-cups-to-nauru>.

146 Alanna Maycock, 'Speech Notes from AMA Forum on Asylum Seekers', (Speech delivered at the Australian Medical Association Forum: The Health Care of Asylum Seekers and the Harms caused by Immigration Detention, Especially for Children, Sydney, 21 February 2016) $<$ https://ama.com.au/ sites/default/files/Ms_Alanna_Maycock_Speech.pdf $>$.

147 Durkin (n 4) 160-61.

148 Note the positive example of NYC's decision to provide menstrual products free to prisoners. 
'facilities'. ${ }^{149}$ Lack of access to sanitary products has been described as discriminatory in government reports. For example, the NT Royal Commission Report discussed above stated that denial of access to menstrual products 'was inconsistent with the human right to be free from discrimination on the grounds of sex'. ${ }^{150}$

The Queensland Anti-Discrimination Commission considered the issue of strip searching and discrimination. ${ }^{151}$ The Commission was of the view that strip searching of female detainees - mandatory in order to have family visits - might be indirect discrimination. This was because it imposed an unreasonable requirement on women - more women than men were likely to choose not to have family visits in order to avoid having to comply with this requirement due to the higher rates of sexual assault trauma among women detainees. ${ }^{152}$ It might also constitute disability discrimination given the more frequent use of strip searching in crisis units where being placed in these units relates to a mental health condition or period of acute mental distress, given that it is 'a term or requirement of the prison authorities that a strip-search is conducted on every female prisoner in crisis units each time she leaves or re-enters her cell after being in another part of the unit or prison' resulting in searches up to six times per day. ${ }^{153}$ In relation to whether the indirect discrimination is 'reasonable' and hence lawful, the Commission stated:

While the use of certain drugs continues to be illegal in Queensland, and certain prisoners are at high risk of self-harm, or pose a serious escape risk, it could be argued that the use of strip searching is reasonable and justified, if no other forms of searching are as effective.

However, if an individual prisoner is assessed as having a low risk of escape or self-harm, routine mandatory strip-searching may not be reasonable. ${ }^{154}$

Gender inequality by reason of strip searching menstruating women might, however, be caught by various exemptions. For example, s 7B of the $S e x$ Discrimination Act 1984 (Cth) exempts indirect discrimination if it is 'reasonable in the circumstances'. The Queensland Anti-Discrimination Commission also noted possible exemptions under the Anti-Discrimination Act 1991 (Qld) that may apply: 'public health (s107), workplace health and safety (s108), and acts done in compliance with legislation (s106)'. However, the frequency of strip-searching might render it indirect discrimination. ${ }^{155}$ The Commission recommended a reduction of the number of strip searches on women in crisis units and the amendment of policies to ensure that women detainees are not subjected to less favourable treatment than males in relation to family visit strip searches. ${ }^{156}$

149 Sex Discrimination Act 1984 (Cth), ss 4 ('services'), 22(1). In the context of states and territories, see, eg, Anti-Discrimination Act 1977 (NSW) ss 4 (definition of 'services'), 33; Equal Opportunity Act 2010 (Vic) ss 4 (definition of 'services'), 44. Gaze and Smith explain that corrections were counted as a service in a case requiring a prisoner's halal diet, however prison management is not: Gaze and Smith (n 60) 154.

150 NT Royal Commission Report (n 139) vol 2A, 450.

151 Anti-Discrimination Commission Queensland (n 135).

152 Ibid 74

153 Ibid.

154 Ibid.

155 Ibid.

156 Ibid 76 
In this example of strip-searching, discrimination law relates to the provision of the 'service' of detention, rather than the fact of inequality in relation to incarceration. Thus, there are challenges in using sex discrimination legislation in a carceral context because of both the taken-for-granted status of incarceration per se, ${ }^{157}$ as well as the structural conditions that result in certain population groups being more likely to end up incarcerated. Yet, these structural features are central to the inequality related to menstruation experienced by women who are incarcerated. ${ }^{158}$ For example, in the Human Rights Law Centre Report on strip searching, the authors acknowledge that Indigenous women, women with mental illness and women with disabilities are over-represented in prison populations and will also be disproportionately impacted by strip searching. ${ }^{159}$ They explain: 'Marginalisation, violence, oppression and discrimination, and their cumulative and intersecting effects, in turn influence the experience and frequently exacerbate the harm of strip searches'. ${ }^{160}$ To this end, the Human Rights Law Centre Report makes recommendations not only concerning the use of strip searching, but also the reduction of the number of women in prison.

Being mindful of Fredman's multidimensional approach to equality, the discussion in this section has illuminated the limits of Australian discrimination law to be transformative because it cannot facilitate structural change for groups of women most at risk of incarceration.

\section{Transgender, Gender-Diverse and Intersex People}

While menstruation is gendered female, in terms of embodiment, it is not only cisgender women who menstruate. As noted by transgender artist and menstrual health activist Cass Clemmer: 'Not all people who menstruate are women, and not all women menstruate'. ${ }^{161}$ Various people across the sex and gender spectrums

157 Roberts (n 130) 22.

158 See, eg, discussion of systemic discrimination and policing in Kat Armstrong, Vicki Chartrand and Eileen Baldry, Submission to the Anti-Discrimination Commissioner, Inquiry into the Discrimination Experienced by Women Prisoners within the Criminal Justice System in New South Wales, May $2005<\mathrm{http}$ //www.justiceaction.org.au/prisons/prison-issues/94-women/597-beyondbars-inquiry-into-treatment-of-women>:

Women, by virtue of their social and economic disadvantage, often find themselves reliant on the services and support of the state. As a result, the state becomes increasingly more involved in the everyday lives of women. Consequently, the greater the disadvantage, the greater the state becomes involved in their affairs. This increased intrusion into and scrutiny of the lives of disadvantaged women often results in their subsequent criminalisation.

159 Rachel Ball and Adrianne Walters, 'Total Control: Ending the Routine Strip Searching of Women in Victoria's Prisons' (Report, Human Rights Law Centre, 2017) 16-7 <https://static1.squarespace. com/static/580025f66b8f5b2dabbe4291/t/5a287bb50d9297f066fd588d/1512602586016/TC+Report Online.pdf> ('Human Rights Law Centre Report').

161 Chloe Sargeant, 'Transgender Activist Tackles the Issue of Menstruation with Powerful Viral Photo', SBS News (online), 24 July $2017<$ https:/www.sbs.com.au/topics/sexuality/agenda/article/2017/ 07/24/transgender-activist-tackles-issue-menstruation-powerful-viral-photo $>$. See also Jen Bell, 'Talking about Periods Beyond Gender', Clue (online), 27 April $2017<$ https:/helloclue.com/ articles/cycle-a-z/talking-about-periods-beyond-gender>; Deepika Bhardwaj, "II Am a Woman, and I Don't Menstruate': Why Menstruation Isn't Only a Women's Issue', The Better India (online), 22 August $2017<$ https://www.thebetterindia.com/112705/menstruation-womens-issue-transgendernon-binary-periods/>. Przybylo and Fahs note that '[w]hile menstruation is mostly coded as a 
respectively may menstruate. Gender inequality arising from menstruation exists, but might take different forms, in relation to transgender and gender-diverse people (gender), and intersex people (sex), and certainly this is gaining more recognition in popular media. ${ }^{162}$ For example, a trans man who is menstruating may encounter misunderstanding alongside disgust due to sexism and transphobia. ${ }^{163}$ Similarly, a person who identifies as being gender-diverse or of non-binary gender may already face public pressure to categorise themselves more definitively as 'male' or 'female'. ${ }^{164}$ Also, a person who is intersex may face 'othering' and conflation of sex (a physiological characteristic) with gender (an identity). ${ }^{165}$ When such individuals are discriminated against on the basis of their menstruation, which is likely to be abnormalised when the person is not a ciswoman, existing prejudices and disadvantage against their LGBTQI+ ('Lesbian, gay, bisexual, transgender, queer and intersex') status may be exacerbated further.

Scholarly engagement in relation to gender inequality, menstruation and transgender, gender-diverse and intersex people requires legal responses that do not conflate gender inequality with discrimination against ciswomen. ${ }^{166}$ The association between menstruation and ciswomen can be discriminatory for ciswomen and, additionally, for those who do menstruate but do not conform to conventional female gender image or roles. In the latter circumstances, administrative systems, health services, health information and education and other structures that address menstruation as associated with ciswomen can themselves enforce further

cisgender female experience, bodies of various genders menstruate and experience menstrual and endometrial pain' and menstrual bleeding is 'complex: it is both highly gendered and not attached as a material reality to only one gender': Przybylo and Fahs (n 8) 208-9.

162 See, eg, Evaan Kheraj and Vera Papisova, 'Intersex People Talk Periods and Dating', Teen Vogue (online), 29 June 2017 <https://www.teenvogue.com/story/intersex-periods-dating>; Rachel Hosie, 'Transgender Male Model Fronts New Period Campaign', The Independent (online), 15 March 2018 $<$ https://www.independent.co.uk/life-style/period-campaign-transgender-male-model-kenny-jonesface-pink-parcel-im-on-stigma-a8257131.html>; Basil Soper, 'To Bleed or Not to Bleed: A Man and His Period', Harpers Bazaar (online), 7 July $2017<$ https://www.harpersbazaar.com/culture/features/ a10224369/trans-man-period/>; Julie Mazziotta, 'Transgender Activist Freebleeds to Show Men Can Menstruate Too: It's "Harmful to Equate Periods with Womanhood", People (online), 25 July 2017 $<$ https://people.com/bodies/transgender-activist-freebleed-men-can-menstruate/ $>$.

163 In May 2018, controversy erupted when staff at New Zealand's University of Otago confiscated copies of the student magazine focusing on menstrual inequality on campus. The cover illustration showed a gender non-specific person menstruating: Eleanor Ainge Roy, 'Otago University Seizes and Destroys Copies of Student Magazine Depicting Menstruation', The Guardian (online), 23 May 2018 $<$ https:/www.theguardian.com/world/2018/may/23/otago-university-seizes-and-destroys-copies-ofstudent-magazine-that-depict-menstruation $>$.

164 Tyler Ford, 'My Life Without Gender: "Strangers are Desperate to Know What Genitalia I Have", The Guardian (online), 8 August $2015<\mathrm{https}$ ://www.theguardian.com/world/2015/aug/07/my-lifewithout-gender-strangers-are-desperate-to-know-what-genitalia-i-have> .

165 Morgan Carpenter, "Normalization" of Intersex Bodies and "Othering” of Intersex Identities' in Jens Sherpe, Anatol Dutta and Tobias Helms (eds), The Legal Status of Intersex Persons (Intersentia, 2018) 445.

166 Such scholarly engagement could draw on the rich scholarship on transgender jurisprudence: Chris Dietz, 'Governing Legal Embodiment: On the Limits of Self-Declaration' (2018) 26(2) Feminist Legal Studies 185; Dean Spade, Normal Life: Administrative Violence, Critical Trans Politics, and the Limits of Law (South End Press, rev ed, 2015); Sally Hines, Gender Diversity, Recognition and Citizenship: Towards a Politics of Difference (Palgrave Macmillan, 2013); Alex Sharpe, Transgender Jurisprudence: Dysphoric Bodies of Law (Cavendish, 2002). 
discrimination through imposing arbitrary gender segregation in how people are categorised and, in turn, treated in relation to their menstruation.

A deeper level of complexity in intersectional discrimination is illustrated by inequality related to menstruation that manifests in very specific ways for incarcerated transgender, gender-diverse and intersex people. While there is limited empirical data on this in Australia, recent government reports related to incarcerated women, discussed above in Part VB, suggest this is of concern. For example, in the Human Rights Law Centre Report on strip searching, the authors acknowledge (without specifically addressing menstruation) that transgender, gender-diverse and intersex people will also be disproportionately impacted by strip searching. ${ }^{167}$ There is more available data overseas. Spade, a US scholar, relates an account of a transgender man with intersex features who was degraded by prison officers when he menstruated:

Jim, a 25-year-old transman, was desperate for help: he was facing a severe threat of rape and already experiencing harassment. ... The jail administration's refusal to continue Jim's testosterone treatments had caused him to menstruate; when Jim was strip searched while menstruating, other inmates and staff learned of his status. ${ }^{168}$

The US Sylvia Rivera Law Project has noted the significant discrimination experienced by transgender men in prison:

The men we represent are already denied their gender identity on a regular basis. Our clients experience continual refusal by correctional officers to be referred to with the rights [sic] names or pronouns, continual refusal to have their gender identity respected, and punishment for any expression of masculinity. Menstrual health products are no more gendered than toilet paper or other necessities of daily living, yet we continue to live in a world where many men are shamed for the needs of their body, and everyone from other incarcerated people to DOCCS [Department of Corrections and Community Supervision] staff use the need for menstrual health products to reify shameful messages about the body and transphobic tropes. No person who needs to use menstrual health products should have to rely on another individual to access them. ${ }^{169}$

The Project report notes that there is also a racialised dimension to this inequality because black transgender men were more likely to spend time in solitary confinement, which limited their access to work to earn money to purchase sanitary products. ${ }^{170}$ These issues of gender inequality and menstruation fit into a broader matrix of discrimination and violence experienced by transgender, gender-diverse and intersex people in carceral settings. ${ }^{171}$ They also reflect socioeconomic factors that might impact on their criminalisation — for example, expense of accessing

Human Rights Law Centre Report (n 159) 16-7.

168 Dean Spade, Normal Life: Administrative Violence, Critical Trans Politics, and the Limits of Law (South End Press, 2011) 7-8.

169 Sylvia Rivera Law Project, Ensure Access to Menstrual Products for People in NYS Custody $<\mathrm{https}$ ://srlp.org/action/ensure-access-to-menstrual-products-for-people-in-nys-custody/>.

170 Ibid.

171 Natasha Frost, 'Are Trans Inmates Safe in Prison?', Radio NZ (online), 23 October 2015 $<$ https://www.radionz.co.nz/news/national/287712/are-trans-inmates-safe-in-prison>. 
hormone treatment, and social isolation due to stigma associated with people who do not conform to 'typical' gender or sex norms. ${ }^{172}$

The growing awareness of LGBTQI+ issues and the expanded boundaries of how we understand sex and gender require adaptations to the traditional approaches to discrimination law and other areas of the law in relation to menstruation. Arguably, this has been achieved to some extent through reforms to discrimination legislation. In 2013, the Australian Parliament amended the Sex Discrimination Act 1984 (Cth) to extend protection from discrimination to grounds of sexual orientation, intersex status, and gender identity. ${ }^{173}$ These widely defined protected attributes have also been adopted in South Australia, the Australian Capital Territory, and Tasmania, ${ }^{174}$ while the other states and territories each protect a variation of sexual orientation and gender identity, but not intersex status. ${ }^{175}$ However, the effectiveness of these reforms and protections have not necessarily been explored and tested in relation to menstruation. As menstruation is a physiological characteristic associated with the female sex, as discussed above, it is arguable that a court may treat discrimination on the basis of menstruation as being solely sex discrimination, rather than discrimination on the basis of gender identity or intersex status. However, a person may menstruate while not being of predominantly female 'sex'. Again, the requirement to identify discrimination on the basis of one particular attribute in Australia may limit the ability for transgender, gender-diverse and intersex people to seek remedies under discrimination law.

\section{Concluding Thoughts and Areas for Further Inquiry}

In an era of renewed feminist activism and scholarly focus on gender equality, we must be attentive to the diverse and perhaps unexpected ways that inequality, discrimination and violence play out. This article was prompted by an interest in how discrimination is enacted specifically through the experience of menstruation. We have demonstrated the pervasive nature of discrimination related to menstruation across a range of social sites and have highlighted the importance of bringing a multidimensional and intersectional approach to equality to understand the full extent (and diversity of experience) of this discrimination. Understanding this discrimination as an issue of reproductive justice enables us to think about how private bodily matters are shaped by economic and social forces, historical factors such as colonialism and eugenics, and how systemic issues of poverty, race and gender shape the bodily experiences of women and girls in different ways and spaces.

172 See, eg, Lisa R Miller and Eric Anthony Grollman, 'The Social Costs of Gender Nonconformity for Transgender Adults: Implications for Discrimination and Health' (2015) 30(3) Sociological Forum 809.

173 Sex Discrimination Amendment (Sexual Orientation, Gender Identity and Intersex Status) Act 2013 (Cth); Sex Discrimination Act 1984 (Cth) ss 4, 5B, 5C.

174 Discrimination Act 1991 (ACT) Dictionary (note 2 and definition of 'intersex status'), s 7(1)(k); Interpretation Act 1915 (SA) s 4(1); Equal Opportunity Act 1984 (SA) s 4(1); Anti-Discrimination Act 1998 (Tas) ss 3, 16(eb).

175 Equal Opportunity Act 2010 (Vic) s 4; Equal Opportunity Act 1984 (WA) s 35AB; AntiDiscrimination Act 1977 (NSW) s 38A; Anti-Discrimination Act 1992 (NT) s 4; Anti-Discrimination Act 1991 (Qld) Dictionary (definition of 'gender identity'). 
Our discussion suggests that Australian discrimination law should be used to address discrimination related to menstruation through creative efforts to bring such claims within the existing framework of the law. This would be strategically valuable in surfacing previously 'unmentionable' issues concerning women's bodies into the public space of law. However, our discussion also suggests that Australian discrimination law is limited in its capacity to address discrimination related to menstruation, since it has been quite narrowly defined and applied. As a result, it cannot address structural inequality and achieve transformative change. In addition, as shown by our discussion of discrimination related to menstruation facing incarcerated women, women and girls with disability, and transgender, genderdiverse and intersex people, the structure of Australian discrimination law is attributebased and cannot address the complex intersections of sex and other attributes.

Thinking across the intersectional examples we have provided, we can identify three important methodological directions for future scholarship on menstruation, gender inequality and Australian discrimination law. The first is attending to disconnected, hidden and unexpected places for laws and policies impacting on menstruation. For example, taxation laws as applied to incarcerated women might not be as directly relevant as laws and operational guidelines on how institutional spaces are managed. For women with disabilities, laws on discrimination in the workplace might not be as pertinent as substituted decisionmaking laws that enable others to make decisions to supress or remove a woman's ability to menstruate. Broader laws that enliven hierarchies of privilege between women, and that structurally expose some women to greater risk of being disabled or incarcerated, are also important areas of critique. ${ }^{176}$

The second methodological direction is being open to tensions between law's application and relevance to different groups of women. In part, this involves contending with the contradictions in how different groups of women occupy and experience public and private spaces and the implications of this for addressing discrimination related to menstruation in ways that implicitly assume menstruators are consumers and workers.

The third methodological direction, drawing on arguments made by O'Connell, ${ }^{177}$ is to be mindful of the relationship between discrimination law and 'normalised embodiment'. This requires us to reflect on the extent to which discrimination law can contend with diverse and abject embodiment or itself is premised on and reifies normalised embodiment.

In starting to trace a broader research agenda on menstruation and inequality, there is much scope for further scholarship, including in the following areas:

(1) The use of different legal methods to address menstrual inequalities, for example, legislative reform, judicial decision-making, policy frameworks and truth commissions;

176 Jasbir Puar, Right to Maim: Debility, Capacity, Disability (Duke University Press, 2017).

177 O’Connell (n 74). 
(2) The place of menstrual pain and its impact on experiences of discrimination related to menstruation;

(3) The implications of perceived impacts of hormones and menstruation on women's behaviour ranging from judicial and managerial decisionmaking through to criminal offending;

(4) The legal and equality dynamics of pharmaceuticals and biotechnologies relating to menstruation and female hormones more broadly;

(5) The legal and equality issues that emerge at the intersections of sustainable menstrual products and environmental justice;

(6) Discrimination related to menstruation within international human rights law and international development law; and

(7) Redress for historical and contemporary menstruation injustices. 
